\title{
Management Strategies and Stakeholders Analysis to Strengthen the Management and Use of Biosolids in a Colombian Municipality
}

\author{
Camilo Venegas ${ }^{1, * \mathbb{D}}$, Andrea C. Sánchez-Alfonso ${ }^{2}$, Crispín Celis ${ }^{3, * \mathbb{C}}$, Fidson-Juarismy Vesga ${ }^{1} \mathbb{C}$ \\ and Mauricio González Mendez ${ }^{4}$
}

1 Department of Microbiology, Grupo de Biotecnología Ambiental e Industrial (GBAI), Laboratorio Calidad Microbiológica de Aguas y Lodos (CMAL), Pontificia Universidad Javeriana, Carrera 7 No. 43-82, Bogotá 110231, Colombia; vesga.f@javeriana.edu.co

2 Gestión Ambiental Sostenibilidad y Territorio (GAMSTE), Corporación Autónoma Regional de Cundinamarca, Avenida Calle 24 (Esperanza) \# 60-50, Centro Empresarial Gran Estación, Costado Esfera-Pisos 6-7, Bogotá 111321, Colombia; asanchez-a@javeriana.edu.co

3 Department of Chemistry, Pontificia Universidad Javeriana, Carrera 7 No. 43-82, Bogotá 110231, Colombia

4 School of Environmental and Rural Studies, Pontificia Universidad Javeriana, Transversal 4 No 42-00, Piso 8 ${ }^{\circ}$, Bogotá 110231, Colombia; gonzalez.alex@javeriana.edu.co

* Correspondence: c.venegas@javeriana.edu.co (C.V.); crispin.celis@javeriana.edu.co (C.C.)

Citation: Venegas, C.;

Sánchez-Alfonso, A.C.; Celis, C.;

Vesga, F.-J.; Mendez, M.G.

Management Strategies and

Stakeholders Analysis to Strengthen the Management and Use of Biosolids in a Colombian Municipality. Sustainability 2021, 13, 12180. https://doi.org/10.3390/su132112180

Academic Editor: Isabella Pecorini

Received: 30 September 2021

Accepted: 26 October 2021

Published: 4 November 2021

Publisher's Note: MDPI stays neutral with regard to jurisdictional claims in published maps and institutional affiliations.

Copyright: (C) 2021 by the authors Licensee MDPI, Basel, Switzerland. This article is an open access article distributed under the terms and conditions of the Creative Commons Attribution (CC BY) license (https:/ / creativecommons.org/licenses/by/ $4.0 /)$.

\begin{abstract}
The difficulties in the management and use of biosolids in Colombia make it necessary to evaluate and analyze the factors involved through various methodologies to achieve the effective management and recycling of this type of waste. The objective of this study was to evaluate the management of sludge and biosolids from a WWTP in a Colombian municipality through the application of three methodologies (SWOT/TOWS, surveys, and stakeholder (player) weighing) for their subsequent use in agriculture. As a result, strategies were proposed at the regulatory, organizational policy, and entity integration levels, among others. It was identified that about $93.6 \%$ of the people surveyed had a positive attitude towards the use of biosolids in agriculture, despite recognizing the existence of a risk $(27.3 \%)$ in this type of practice. On the other hand, regarding the communication of WWTP management of these wastes, they perceived that it to be absent (65\%) and the lack of knowledge regarding the destination of these wastes was even greater $(72.7 \%)$. Through the weighting of actors, 16 players were classified with whom it is necessary to work closely, regularly, or occasionally. The methodologies proposed will allow similar WWTPs to optimize their processes through continuous improvement and joint work between the different entities and communities. It is recommended that other methodologies be used to evaluate player position level in relation to planned strategies, as well as the level of associations of one player with another, independent of power and influence.
\end{abstract}

Keywords: agriculture; biosolids; players or interested parties as stakeholders; solid waste management; SWOT; TOWS; WWTP

\section{Introduction}

Worldwide, about $359.4 \times 10^{9} \mathrm{~m}^{3} /$ year of wastewater is produced, of which $63 \%$ is collected, it is estimated that about $52 \%$ of the wastewater is treated in wastewater treatment plants (WWTPs) while the other $48 \%$ is not treated at all [1].

In Colombia, between 2018 and 2019, about 913 and 993 million $\mathrm{m}^{3}$ of wastewater were treated, of which $42.85 \%$ and $48.56 \%$ corresponded to domestic origin, thus presenting an increase of 5.71\% compared to 2018 [2]; however, in less favored areas, the coverage rates are lower compared to urban areas [2-5].

As a result of the sedimentation process in wastewater treatment, sludge is obtained, which concentrates compounds that were present in the wastewater and that were removed 
by the unitary operations that make up a WWTP [6-9]. Thus, this sludge presents a high risk to the environment and to humans; therefore, it must be stabilized until a product known as biosolid is obtained, which can be used in different activities [10-13].

Globally, about $2.5 \times 10^{7}$ to $6.0 \times 10^{7}$ tons of dry biosolids are produced per year [14,15], mostly destined for agricultural activities, being the most beneficial and economic option compared to other forms of recycling or disposal, especially for areas with technical, operational, or economic limitations [16-23]. In some Latin American countries, the issue of biosolids regulation, production, stabilization, and utilization has not been widely developed due to substantial differences in economic, technical, infrastructure, and management development compared to other regions or countries [5,24-30].

In Colombia, in 2018 and 2019, seven cities and four municipalities generated a total of 250,172 , and 134,900 tons of biosolids, respectively [31], amounts higher than those reported in previous years [26,32]. On the other hand, it has been identified that biosolid quality assessments, under the Decree 1287 of 2014 [33], are carried out partially in some WWTPs; the microbiological parameters are reported in units different from those established in the standard [33]; in some cases, detection methods are not appropriate for the type of matrix used; and, in most cases, the detection of viruses or somatic coliphages, being required by the Colombian regulations, is not performed.

Regarding the use of biosolids, it has been observed that in Latin America reuse in agricultural activities predominates, as is the case in some regions of Chile, which, between 2009 and 2017, increased the use of biosolids in such activities, attaining an advantage of about $75 \%$ of produced biosolids undergoing various challenges involved in its reuse [34-36]. In Brazil, in the state of Paraná, about 285,836 tons were disposed in 15,423 ha of agricultural land in the decade from 2007 to 2017 [37]. In Colombia, the use of biosolids has been concentrated in some specific activities (soil restoration in quarries, improvement of degraded soils and preparation of land for livestock entry, slope stabilization, planting of ornamental plants and shrubs) [38-41], while their use in agriculture is almost absent despite the existence of regulations governing this activity [33]; however, some studies have been conducted to evaluate this type of practice [31].

The Colombian cities that carried out the most utilization activities in 2018 and 2019 were Medellín, Cali, Ibagué, and Piedecuesta (Santander), using about $5 \%$ to $65 \%$ of the total biosolids produced [31,40]; however, there are several WTTPs of municipalities or intermediate cities that treat wastewater of domestic origin and do not perform any type of recycling of biosolids, they dispose it without carrying out stabilization in accordance with the regulations.

Recently, Colombia has seen the need to propose sustainable models for different sectors, such as the circular economy, green business, and green growth, which include reuse, the use of non-conventional energy sources, efficiency models, among other practices [42-45], to reduce or change the linear production model that leads to disposal. Such is the case of wastewater management and the by-products generated from wastewater treatment, in which the aim is to identify the potential and business opportunities of these elements within the countryproduction cycle $[43,46]$.

The use of biosolids in agriculture has become one of the most relevant options in Colombia. It is one of the most sustainable and economical methods, especially for areas with certain limitations. The benefits that they bring to the site, as well as the producers, transformers, and farmers, are important; it highlights the agricultural capacity of Colombia [47]. These issues are the most studied in Colombia in recent years. Without underestimating their importance in their evaluation, it is necessary for research to look beyond traditional management and not solely focus on describing and evaluating biosolids from a technical point of view. This was the case in the studies carried out on the application of these to the soil, on a small scale or in specific places (21.7\%), pathogen stabilization and reduction processes $(34.8 \%)$, evaluation of reuse alternatives $(26.1 \%)$, update of guidelines or regulations $(6.5 \%)$, among other studies (Figure 1). It is necessary to strengthen the traditional management of biosolids in Colombia and recognize other aspects that may 
influence its use. Agriculture is a specific activity that has not been evaluated and is an issue that generates diverse positions.

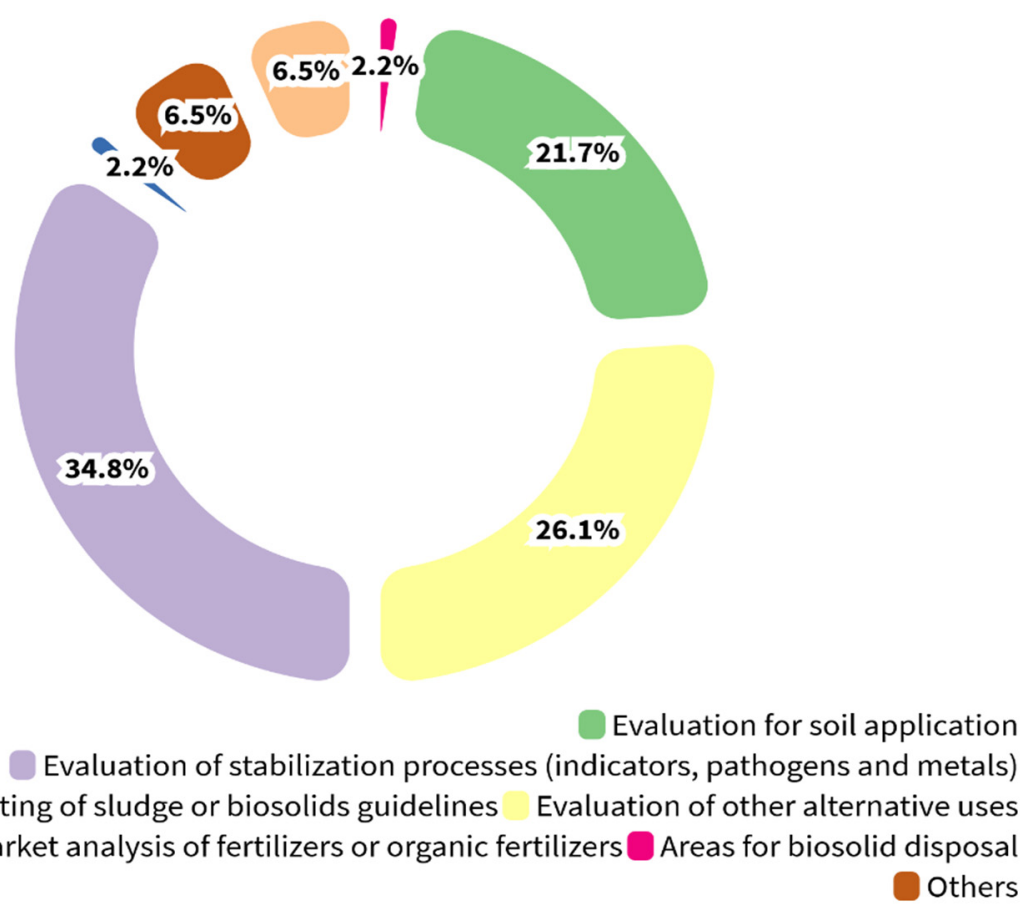

Figure 1. Research on sludge and biosolids in Colombia from 2002 to 2021.

The analysis of new ways to carry out the application of biosolids in agriculture from another perspective is required. It is necessary to achieve the objectives proposed within the Colombian government policy through document CONPES 4004 [43]. The contemplation and study of new variables that can be analyzed and represented through tools used for environmental management are crucial for the application and use of these compounds. Research can help to establish a new method to make, evaluate, and carry out the use of organic waste.

Biosolids management and their use in agriculture represents a challenge for developing countries due to the complexity of generating an efficient, effective and sustainable management and reuse process [48-52]. At the municipal level, these challenges are even greater due to the difficulties in developing their own management, mainly because of economic, technical, and infrastructure limitations. Therefore, it is necessary to analyze other complementary aspects at the municipal level, such as evaluation of the management of the present WWTPs for subsequent formulation of strategies based on the current treatment plant possibilities, and the challenges that arise from the management and use of these wastes. This will allow for management changes and strengthening because, in most cases, WWTP management studies and reports focus only on water resource management and stabilization mechanisms for biosolids.

The strengths, weaknesses, opportunities, and threats (SWOT) analysis is one of the most widely used tools in different types of organizations, because it allows the identification and analysis of quantitative and qualitative aspects based on the identification of internal and external factors of the organization, which allows for the generation of management and planning strategies [53-58]. However, it is suggested to complement the evaluation with the combination of other tools to strengthen it and counteract SWOT limitations $[59,60]$.

The players or stakeholders are fundamental in the development and sustainability of a waste utilization system due to the interests, powers, and influence they represent [61-63], even more so considering the different positions that can be generated by the use of a product obtained from the treatment of domestic wastewater [21,64-66]. Therefore, 
its analysis becomes relevant because the development of some type of strategy would imply the participation and integration of various sectors or entities, both directly and indirectly [21,48-50]. Likewise, their inclusion provides new criteria, information, and supply of variables that will allow strengthening waste reuse, even if they are considered as isolated agents with discontinuous interaction [67].

The characterization and study of the players can be carried out in several ways. Among the most used methods are qualitative, quantitative, and participative analyses [68-72]. These are carried out by diagramming or mapping players according to the level of association between the following aspects: power/influence [73], power/interests [67,71,74-76], knowledge/attitude [74], attitude/interest [75], and influence/dependence [77]. With these analyses, in addition to the characterization and identification of players positioned within a system, it is also possible to recognize problems, challenges, and limits that the interaction between each of these players may present $[73,78,79]$.

As aforementioned, the three objectives of this study were: (I) to evaluate the current management of sludge and biosolids from a WWTP in a municipality in Colombia, with the intention of using biosolids in agriculture; (II) to determine the main players that can influence the management of the WWTP and the process of inclusion of biosolids in the agricultural sector; (III) to propose a series of strategies to improve the management and use of biosolids in agriculture, at the regulatory level, in the WWTPs and in the connection and work between players.

\section{Materials and Methods}

\subsection{Location and Characteristics of the WWTP}

The WWTP evaluated is located in the department of Boyacá, Colombia, and receives water collected by the sewage system of the municipal seat, which is a combined sewer system, whose wastewater inputs are mainly from domestic, institutional, and commercial sources, with the respective stormwater input. This water receives aerobic biological treatment, carried out through the activated sludge process in a sequencing batch reactor (SBR), which consists of a sequence of filling and emptying cycles of the reactors. Reactor-generated biosolids go through a process of centrifugation, addition of polymer, and stabilization through the addition of lime. Finally, they are transferred to chambers located directly on the ground next to the WWTP infrastructure (Table 1). From previous analyses, it was possible to determine microbiological indicator concentrations, pathogenic microorganisms, and heavy metals [80]. It was evident that the performed stabilization process did not comply with class B biosolids characteristics and parameters, according to Decree 1287 of 2014 of the Department of Environment of Colombia [33], thus hindering its use.

Table 1. Description of the WWTP treatment evaluated.

\begin{tabular}{|c|c|c|c|c|c|c|}
\hline $\begin{array}{c}\text { Treatment/Flow } \\
\text { Treatment }\end{array}$ & $\begin{array}{l}\text { Population } \\
\text { Served }\end{array}$ & Water Line & $\begin{array}{l}\text { Sludge } \\
\text { Treatment }\end{array}$ & $\begin{array}{c}\text { Type of Sludge } \\
\text { Stabilization }\end{array}$ & $\begin{array}{c}\text { Time of } \\
\text { Treatment or } \\
\text { Stabilization }\end{array}$ & $\begin{array}{l}\text { Quantity of } \\
\text { Treated Sludge } \\
\text { Generated }\end{array}$ \\
\hline $\begin{array}{c}\text { SBR, AS/ } \\
240 \text { to } 252 \text { lps }\end{array}$ & $\begin{array}{l}\sim 72.770 \\
\text { people }\end{array}$ & $\begin{array}{l}\text { Pretreatment, } \\
\text { primary, secondary, } \\
\text { tertiary (UV light) } \\
\text { treatment }\end{array}$ & $\begin{array}{c}\text { Thickeners } \\
\text { (polymers) } \\
\text { and } \\
\text { dewatering }\end{array}$ & Lime-treated & $\sim 1$ month & $\begin{array}{l}\sim 480 \\
\text { tons/year }\end{array}$ \\
\hline
\end{tabular}

: Approximately, SBR: sequencing batch reactor, AS: activated sludge.

\subsection{SWOT Analysis}

The SWOT analysis was carried out based on the identification and collection of information from Colombian regulations, institutional documents, and reports from public and private entities related to the generation, control, and use of sludge and biosolids $[2,3,33,43,81-84]$. The selected and analyzed documents corresponded to the period 2014 to 2020. On the other hand, management and operation reports of the WWTP and the environmental authority in 
charge of its control corresponding to the period 2019 to 2021 were reviewed [31,80,85-87]. A total of 14 documents were reviewed and each of them was analyzed in terms of the favorable and unfavorable aspects regarding the regulations, management, and reuse of biosolids in agriculture, as this is a projected use activity for the coming years in the municipality where the WWTP is located.

From this analysis and the criticality status of each of the identified variables, two SWOT matrices were obtained, which corresponded to (I) biosolids management according to Colombian regulations and (II) biosolids management of the WWTP evaluated. For each of the scenarios, two strategy matrices (TOWS) were proposed based on the relationships between threats, opportunities, weaknesses, and strengths, resulting in four groups of strategies: Strength-opportunity (SO)—strategies that use strengths to maximize opportunities; weaknesses-opportunities (WO)—strategies that minimize weaknesses by taking advantage of opportunities; strength-threats (ST)—strategies that use strengths to minimize threats; weaknesses-threats (WT)—strategies that minimize weakness and avoid threats [55].

\subsection{Stakeholder Analysis}

Stakeholders were identified at the national, departmental, and municipal levels as those who were or could be related to the management and utilization practices of this type of waste, who were then contacted. Subsequently, each stakeholder was characterized according to their functions and roles (Appendix A-Table A1). Next, the survey was sent using the Google forms ${ }^{\odot}$ software. The stakeholders were divided into two groups-(I) public and private entities and (II) community.

Public, Private, and Community Entities

Within the group of public and private entities, 28 actors participated, including: WWTPs of cities and municipalities, control or surveillance agencies (e.g., Regional Autonomous Corporation of Cundinamarca (Corporación Autónoma Regional de Cundinamarca-CAR)), the Colombian Agricultural Institute (Instituto Colombiano Agropecuario-ICA), farmers or associations, agro-industry representatives, academia representatives, waste managers, national entities (e.g., National Planning Department (Departamento Nacional de Planeación-DNP)), and the Economic and Agricultural Development Area (Área de Desarrollo Económico y Agropecuario_DEyA) of the municipality under study (Appendix A-Table A1). For the second group, labelled as community, 178 people participated, of which $86 \%$ corresponded to people residing in cities and $14 \%$ in municipalities in Colombia (Appendix A-Table A1). Due to mobility restrictions generated by the pandemic, no face-to-face interviews were conducted with farmers or inhabitants within the area of influence of the study area.

\subsection{Surveys}

Two types of surveys were designed and applied to public, private, and community entities during the first quarter of 2021. The objectives of the surveys were: (I) assess the perception of the management performed by the WWTPs, (II) evaluate the power and interest of the different stakeholders involved in the management and use of biosolids, (III) determine the challenges in the management and use of biosolids, and (IV) determine the level of knowledge and satisfaction of the management and use system. These objectives were applied to the different stakeholders described in Appendix A-Table A1. Each of the surveys allowed for feedback from the participants themselves, allowing others to make weightings of new variables.

\subsection{Data Analysis}

Collected data from the two surveys were consolidated in Microsoft Excel ${ }^{\odot}$ software and the qualitative assessments were categorized by establishing numerical scales to perform the descriptive analysis and graphic representation of each of the results. The identification and evaluation of the 16 players or stakeholders was carried out by obtaining 
the average of the total of the ratings given by the respondents in the following two systems or scenarios: (I) biosolids management at the treatment plant level and (II) use of biosolids in agriculture.

Power/influence ratings were given on a scale of 1 to 5 , with 1 being low power or influence and 5 being the highest value given. The design of a power/influence matrix or map made it possible to classify the players according to their distribution or location, taking into account the level of authority granted (power) and the capacity to influence the system (influence) (Table 2). For the visualization of the results, the Flourish Studio (Kiln Enterprises Ltd., London, United Kingdom, https:/ / flourish.studio/, accessed on 30 September 2021) was used.

Table 2. Power/Influence Grid.

\begin{tabular}{|c|c|c|c|}
\hline \multirow{4}{*}{ 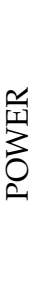 } & High & $\begin{array}{c}\text { Subjects/Maintain satisfied } \\
\text { (HP/LI) }\end{array}$ & $\begin{array}{l}\text { Players/Maintain close } \\
\text { (HP/HI) }\end{array}$ \\
\hline & Low & $\begin{array}{l}\text { Crowd/ Monitor } \\
(\mathrm{LP} / \mathrm{LI})\end{array}$ & $\begin{array}{l}\text { Context Setters/Maintain } \\
\text { informed (LP/HI) }\end{array}$ \\
\hline & & Low & High \\
\hline & & \multicolumn{2}{|c|}{ INFLUENCE } \\
\hline
\end{tabular}

HP/LI: high power, less interested people; HP/HI: high power, highly interested people; LP/LI: low power, less interested people; LP/HI: low power, highly interested people $[68,73,88]$.

\section{Results}

\subsection{SWOT and TOWS Strategies}

Tables 3 and 4 show the strengths, weaknesses, opportunities, and threats identified for each of the Colombian standards evaluated and for the management carried out by the WWTP evaluated. In the analysis of regulations, six strengths and three weaknesses were identified, and in relation to external aspects, nine threats and five opportunities were recognized (Table 3). On the other hand, four strengths, seven weaknesses, six opportunities, and four threats were observed for the management of the WWTP under study (Table 4). Based on the grouping of the total threats, opportunities, weaknesses, and strengths identified in the regulations and in the management carried out by the WWTP, a series of strategies were defined (Tables 5 and 6), which would allow achieving compliance in the short and medium term; these should be undertaken by the different stakeholders to carry out the management improvement process, as well as recommendations for the use of biosolids in agriculture.

Table 3. SWOT analysis of biosolids management in terms of Colombian regulations.

\begin{tabular}{|c|c|c|c|}
\hline $\mathbf{N}$ & STRENGTHS (S) & $\mathbf{N}$ & WEAKNESSES (W) \\
\hline S1 & $\begin{array}{c}\text { Decree } 1287 \text { of } 2014 \text { [33] is based on technical } \\
\text { aspects of EPA } 503 \text { [89]. }\end{array}$ & \multirow{2}{*}{ W1 } & \multirow{2}{*}{$\begin{array}{l}\text { The biosolids regulation does not } \\
\text { contemplate the detection of organic and } \\
\text { emerging compounds. }\end{array}$} \\
\hline S2 & $\begin{array}{l}\text { Establishes the evaluation and determination } \\
\text { of alternative indicators (somatic coliphages.) }\end{array}$ & & \\
\hline S3 & $\begin{array}{l}\text { Contemplates environmental indicators for } \\
\text { biosolids management by WWTPs. }\end{array}$ & \multirow[b]{2}{*}{ W2 } & \multirow[b]{2}{*}{$\begin{array}{l}\text { Most national regulations do not include } \\
\text { efficiency indicators for sanitation or } \\
\text { biosolids utilization. }\end{array}$} \\
\hline S4 & $\begin{array}{l}\text { It establishes that biosolids generators must } \\
\text { report to or inform the Unified Information } \\
\text { System (UIS) of the SSPD about the amounts } \\
\text { generated and the } \\
\text { corresponding characteristics. }\end{array}$ & & \\
\hline
\end{tabular}


Table 3. Cont.

\begin{tabular}{|c|c|c|c|}
\hline $\mathbf{N}$ & STRENGTHS (S) & $\mathbf{N}$ & WEAKNESSES (W) \\
\hline S5 & $\begin{array}{l}\text { Analysis of biosolids must be performed by } \\
\text { certified laboratories. }\end{array}$ & \multirow{2}{*}{ W3 } & \multirow{2}{*}{$\begin{array}{l}\text { The information requested from WWTPs by } \\
\text { public control entities regarding sludge and } \\
\text { biosolids is limited. }\end{array}$} \\
\hline S6 & $\begin{array}{l}\text { Inclusion of by-products generated from } \\
\text { wastewater treatment within the circular } \\
\text { economy model. }\end{array}$ & & \\
\hline $\mathbf{N}$ & OPPORTUNITIES (O) & $\mathbf{N}$ & THREATS (T) \\
\hline O1 & $\begin{array}{l}\text { It is proposed to analyze the costs of sludge } \\
\text { and biosolids generation and treatment. }\end{array}$ & $\mathrm{T} 1$ & $\begin{array}{l}\text { There is no certified laboratory in the country } \\
\text { that performs the detection of enteric viruses } \\
\text { or somatic coliphages in sludge } \\
\text { and biosolids. }\end{array}$ \\
\hline \multirow{3}{*}{$\mathrm{O} 2$} & \multirow{3}{*}{$\begin{array}{l}\text { The national government plans to strengthen } \\
\text { the existing WWTP infrastructure by } 2022 \text {. }\end{array}$} & $\mathrm{T} 2$ & $\begin{array}{l}\text { Lack of greater coordination and } \\
\text { communication between the different entities } \\
\text { for management and control }\end{array}$ \\
\hline & & $\mathrm{T} 3$ & $\begin{array}{c}\text { In most cases, WWTPs are unaware or only } \\
\text { partially aware of the type of sludge } \\
\text { they generate. }\end{array}$ \\
\hline & & $\mathrm{T} 4$ & $\begin{array}{l}\text { Lack of incentives for WWTPs to produce } \\
\text { biosolids that comply with regulations. }\end{array}$ \\
\hline $\mathrm{O} 3$ & $\begin{array}{l}\text { Updating of guidelines (technical, financial, } \\
\text { and environmental requirements) for } \\
\text { biosolids use. }\end{array}$ & T5 & $\begin{array}{l}\text { There is no technical guide for the } \\
\text { management, treatment, and use of biosolids. }\end{array}$ \\
\hline \multirow{2}{*}{$\mathrm{O} 4$} & \multirow{2}{*}{$\begin{array}{l}\text { Proposals to strengthen the institutional } \\
\text { framework, information management, and } \\
\text { governance of water and sewerage services. }\end{array}$} & $\mathrm{T} 6$ & $\begin{array}{l}\text { Little or no information on biosolids is } \\
\text { available on publicly accessible platforms. }\end{array}$ \\
\hline & & $\mathrm{T} 7$ & $\begin{array}{c}\text { Presence of organic contaminants and } \\
\text { emergent substances }\end{array}$ \\
\hline \multirow[t]{2}{*}{ O5 } & \multirow[t]{2}{*}{$\begin{array}{l}\text { There is a proposal [90] to strengthen Decree } \\
\qquad 1287 \text { of } 2014 .\end{array}$} & $\mathrm{T} 8$ & $\begin{array}{l}\text { Failure or delay in the adoption of new } \\
\text { technologies for the treatment and use } \\
\text { of biosolids. }\end{array}$ \\
\hline & & T9 & Neglect or inadequate operation of WWTPs \\
\hline
\end{tabular}

Table 4. SWOT analysis of biosolids management at the evaluated WWTP.

\begin{tabular}{|c|c|c|c|}
\hline $\mathbf{N}$ & STRENGTHS (S) & $\mathbf{N}$ & WEAKNESSES (W) \\
\hline S1 & $\begin{array}{l}\text { The WWTP under study is working on the } \\
\text { improvement of stabilization processes for } \\
\text { dehydrated sludge. }\end{array}$ & W1 & The type of biosolids generated is unknown. \\
\hline \multirow[t]{2}{*}{ S2 } & \multirow{2}{*}{$\begin{array}{l}\text { Preventive and corrective maintenance is } \\
\text { performed on the equipment and } \\
\text { infrastructure of the WWTP. }\end{array}$} & W2 & $\begin{array}{l}\text { Little information on current sludge } \\
\text { management, limiting control, monitoring, } \\
\text { and improvement. }\end{array}$ \\
\hline & & W3 & $\begin{array}{l}\text { The WWTP has some equipment that has } \\
\text { been out of service for several months. }\end{array}$ \\
\hline \multirow{2}{*}{ S3 } & \multirow{2}{*}{$\begin{array}{l}\text { Periodic training is provided to the WWTP } \\
\text { operating personnel. }\end{array}$} & W4 & $\begin{array}{l}\text { No document and variables for sludge } \\
\text { stabilization have been established. }\end{array}$ \\
\hline & & W5 & $\begin{array}{l}\text { No information is reported to the Unified } \\
\text { Information System (UIS). }\end{array}$ \\
\hline
\end{tabular}


Table 4. Cont.

\begin{tabular}{|c|c|c|c|}
\hline $\mathbf{N}$ & STRENGTHS (S) & $\mathbf{N}$ & WEAKNESSES (W) \\
\hline \multirow[b]{2}{*}{$\mathrm{S} 4$} & \multirow{2}{*}{$\begin{array}{l}\text { Between } 2016 \text { and 2019, awareness-raising } \\
\text { sessions were held for the community in } \\
\text { relation to environmental education. }\end{array}$} & W6 & $\begin{array}{l}\text { Lime-stabilized sludge does not generate a } \\
\text { product close to a Class B biosolid. }\end{array}$ \\
\hline & & W7 & $\begin{array}{l}\text { No biosolids management and utilization } \\
\text { policy was identified by the company } \\
\text { operating the WWTP. }\end{array}$ \\
\hline $\mathbf{N}$ & OPPORTUNITIES (O) & $\mathbf{N}$ & THREATS (T) \\
\hline $\mathrm{O} 1$ & $\begin{array}{c}\text { To have the technical support and experience } \\
\text { of control entities (e.g., CAR) in the } \\
\text { management and treatment of sludge } \\
\text { and biosolids. }\end{array}$ & $\mathrm{T} 1$ & $\begin{array}{l}\text { Costs or increments related to improved } \\
\text { sludge treatment, addition of methods, or } \\
\text { operations to improve stabilization. }\end{array}$ \\
\hline $\mathrm{O} 2$ & $\begin{array}{l}\text { The institutions or academic institutions } \\
\text { have personnel trained in sludge treatment. }\end{array}$ & $\mathrm{T} 2$ & $\begin{array}{l}\text { Inadequate process execution and sludge } \\
\text { stabilization time }\end{array}$ \\
\hline $\mathrm{O} 3$ & $\begin{array}{l}\text { Increased dissemination and publication of } \\
\text { information for biosolids management. }\end{array}$ & $\mathrm{T} 3$ & $\begin{array}{l}\text { Complaints and disagreements from the } \\
\text { community due to possible odors, risks and } \\
\text { environmental impacts derived from sludge } \\
\text { treatment. }\end{array}$ \\
\hline $\mathrm{O} 4$ & $\begin{array}{l}\text { Generate interest and community } \\
\text { involvement in the management of } \\
\text { the WWTP. }\end{array}$ & & \\
\hline O5 & $\begin{array}{l}\text { It is proposed to analyze the economic } \\
\text { impacts of sludge/biosolids treatment. }\end{array}$ & $\mathrm{T} 4$ & $\begin{array}{c}\text { Costs and low supply of laboratory analyses } \\
\text { for waste characterization }\end{array}$ \\
\hline O6 & $\begin{array}{l}\text { Promote the interest of organic fertilizer } \\
\text { manufacturers to produce and market } \\
\text { organic fertilizers. }\end{array}$ & & \\
\hline
\end{tabular}

Table 5. TOWS strategic matrix in accordance with Colombian standards.

\begin{tabular}{|c|c|c|}
\hline & SO & WO \\
\hline 1. & $\begin{array}{l}\text { Define and apply the additional costs of sludge treatment } \\
\text { through the compliance and execution of the biosolids } \\
\text { management indicators by the WWTPs (O1, S1, and S3). }\end{array}$ & $\begin{array}{l}\text { Updating of service tariffs to improve aspects of } \\
\text { management, characterization, and stabilization processes } \\
\text { and the use of biosolids (O1, O2, W3). }\end{array}$ \\
\hline 2. & $\begin{array}{l}\text { Strengthen and invest in sludge treatment and } \\
\text { stabilization processes to achieve environmental } \\
\text { management indicators (O2, S1, S2, S3 and S4). }\end{array}$ & $\begin{array}{l}\text { 2. Promote scientific research to develop methods for the } \\
\text { detection and characterization of recurrent emerging } \\
\text { elements and establish the risk generated by their } \\
\text { presence in sludge }(\mathrm{O} 3, \mathrm{~W} 1, \mathrm{~W} 2 \text {, and } \mathrm{W} 3) \text {. }\end{array}$ \\
\hline 3. & $\begin{array}{l}\text { Strengthen the technical capacity and expertise of public } \\
\text { institutions, control, and public water and sewerage } \\
\text { services (O4 and S3). }\end{array}$ & $\begin{array}{l}\text { Strengthen internet pages, platforms, and information } \\
\text { systems of control entities in relation to sludge } \\
\text { management, quality and use (O4, W2, and W3). }\end{array}$ \\
\hline 4. & $\begin{array}{l}\text { Adopt new proposals of guidelines for biosolids standards } \\
\text { in relation to indicators for the use, handling, } \\
\text { management, and control of biosolids. (O5, S1, S3). }\end{array}$ & \multirow{2}{*}{$\begin{array}{l}\text { Strengthening of indicators and goals that allow the } \\
\text { evaluation of WWTP management to achieve the use of } \\
\text { biosolids and reduction of unused waste, favoring the } \\
\text { transition to the circular economy model, which is } \\
\text { projected and coordinated with the policies of the national } \\
\text { government (O1, O2, W3). }\end{array}$} \\
\hline 5. & $\begin{array}{l}\text { Align the policies and actions of public and private } \\
\text { entities in terms of the fulfillment or achievement of } \\
\text { biosolids utilization objectives related to the circular } \\
\text { economy }(\mathrm{O} 5, \mathrm{~S} 1, \mathrm{~S} 6) \text {. }\end{array}$ & \\
\hline
\end{tabular}


Table 5. Cont.

1. Initiate knowledge transfer programs from public and private institutions to environmental laboratories (T1, S1, S3, and S5).

2. Implement and strengthen strategies for the communication and follow-up of the proposed indicators for the evaluation of biosolids management (T2, T3, T5, S3).
1. Unify biosolids characterization parameters based on international models, which will make it possible to obtain complete information on physical and chemical parameters and microbial loads. (W1, T1, T6).

2. Encourage WWTP operators to implement a management system and develop efficiency indicators for the use of biosolids (W2, T3, T4, T8, T9).

3. Establish guidelines for the management and utilization of biosolids based on international experiences and guidelines (T5, S1, and S3).

4. Encourage scientific research for the development of

3. Unify, channel, and strengthen information on sludge line methods for the detection, characterization, and monitoring of emerging compounds, as well as the development and design of complementary processes and treatments for their removal, with their corresponding publication and dissemination to the community (T7, S2, and S4). management, stabilization, recovery, or final disposal in a platform for dissemination to all stakeholders (D3, A2, A5).

SO: strength-opportunity, WO: weaknesses-opportunities, ST: strength-threats, WT: weaknesses-threat.

Table 6. TOWS — strategic matrix for the management of the evaluated WWTP.

\section{SO}

1. Generate links with public or private research groups to improve sludge control and stabilization processes in order to obtain an optimal and marketable product (O1, $\mathrm{O} 2, \mathrm{O} 5, \mathrm{O} 6, \mathrm{~S} 1, \mathrm{~S} 2$, and S3).

2. Approach community groups to disseminate information on the management achieved and plans of the WWTPs (O3, O4, and S4).

3. Develop campaigns to strengthen relations with the agroindustry sector to achieve adoption of biosolids and biosolids use (O2, O4, and $\mathrm{S} 1, \mathrm{~S} 4)$.

\section{WO}

1. Promote integration between control entities and academic institutions to strengthen the management and process improvements of the water and sludge line (O1, $\mathrm{O} 2, \mathrm{~W} 1, \mathrm{~W} 2, \mathrm{~W} 3$, and W4).

2. Encourage, strengthen, and expand the publication of open data on sludge line management $(\mathrm{O} 3, \mathrm{O} 4, \mathrm{O} 6, \mathrm{~W} 2$, and W5).

3. Adoption of an institutional policy based on the treatment of sludge and use of biosolids that will allow receiving benefits from the reuse of biosolids as a finished product (O5, O6, W3, W4, W6, and W7).

4. Strengthen associations between different stakeholders and involvement of the economic and agricultural development sector for joint work to adopt biosolids use (O1, O2, W1, W2, W3, and W4).

5. Establish a corporate policy or vision to focus and work on the use and reduction of organic waste (biosolids) that is not reused $(\mathrm{O} 1, \mathrm{O} 5, \mathrm{O} 6, \mathrm{~W} 1, \mathrm{~W} 2, \mathrm{~W} 7)$.

6. Work on strengthening the policy of accountability of entities and the consolidation of institutional and community support networks (O1, O2, W1, W2, W3, and W4). 
Table 6. Cont.

1. Use cooperation strategies with university laboratories $(\mathrm{S} 1, \mathrm{~T} 4)$
1. Make the company that operates the WWTP aware of the need to allocate the necessary resources for equipment maintenance or upgrades (W3, W4, T3, T4, T1).

2. Allocate the necessary resources for the treatment of sludge and for the application of methods that allow the improvement of biosolids, standardize the method of adding lime (S1, S3 T1, T2, T3).

2. Define and implement procedures for domestic sludge handling and stabilization processes (T1, T2, T4, W4, W5, W6, W7).

3. Strengthen the means of dissemination and communication favoring the visibility of WWTP management in terms of biosolids utilization (S1, S3, T3, T4).

SO: strength-opportunity, WO: weaknesses-opportunities, ST: strength-threats, WT: weaknesses-threats.

\subsection{Stakeholder Surveys}

\subsubsection{Community}

Table 7 describes each of the percentages obtained from the series of questions asked. It is important to note that of the 179 surveyed, $44.1 \%$ knew what a sewage sludge is and $43 \%$ knew what a biosolid is, whereas between $34.7 \%$ and $38.6 \%$ did not know these types of matrices. Regarding the perception of the people surveyed in reference to the level of communication of wastewater management by the WWTPs, it was found that about $38.2 \%$ of those surveyed mentioned that there is no type of communication from these entities. For the question concerning communication of sludge and biosolids management by the WWTPs, $65 \%$ of the respondents mentioned that they were unaware of this activity. Regarding cultivation with biosolids or application of biosolids on crops, $62.7 \%$ had a very positive attitude and $30.9 \%$ had a positive attitude. However, the people surveyed recognized that there is a certain level of risk that could be presented by the application of biosolids on the soil.

\subsubsection{Public and Private Entities}

Of the different players interviewed belonging to the group of public and private companies, such as wastewater treatment plants, control entities, waste managers, farmers or associations, academia, some companies belonging to the agro-industry sector, the DNP, and, at the level of the municipality studied (area in charge of economic and agricultural development), environmental manager of the WWTP, some mentioned that sludge and biosolids management at the general level is between poor (26\%) and fair (37\%) (Figure 2A); while others suggested that sludge and biosolids management at a general level is between poor $(26 \%)$ and fair (37\%) (Figure 2A). In the specific case of the WWTPs of the cities, they considered their management to be good (40\%); however, of the WWTPs of municipalities, they perceived their management to be between poor $(20 \%)$ and fair $(40 \%)$.

The interest of the different stakeholders in improving the management and quality of biosolids was high $(42.9 \%)$ and very high $(35.7 \%)$ interest; however, only $7.1 \%$ of the respondents expressed a low interest (Figure 2B). On the other hand, the position of the different sectors on the use of biosolids in agriculture was between neutral $(29 \%)$ and favorable (64\%) (Figure 2C). In the particular case of farmers, $67 \%$ expressed a neutral position about carrying out this practice, while $33 \%$ had a favorable perception, and for the agro-industry sector, $100 \%$ of the respondents expressed favorability towards this activity. The level of relation the different public and private institutions had with the community to work on perception and dissemination was characterized as low (60\%) (Figure 2D). 
Table 7. Results of the surveys conducted with stakeholders belonging to the general public (community group) related to the management of WWTPs and the perception of the use of biosolids in agriculture.

1. Recognize or know what sewage sludge (from or resulting from) wastewater is

\section{Recognize or know what a biosolid is}

\begin{tabular}{cccc}
\hline Yes & $44.1 \%$ & Yes & $43.0 \%$ \\
\hline No & $34.7 \%$ & No & $38.6 \%$ \\
\hline More or less & $21.2 \%$ & More or less & $18.4 \%$ \\
\hline
\end{tabular}

3. Perception of the level of communication that WWTPs have in relation to wastewater treatment management.

\begin{tabular}{|c|c|c|c|}
\hline High & $11.8 \%$ & High & $0.0 \%$ \\
\hline Medium & $24.5 \%$ & Medium & $10.0 \%$ \\
\hline Low & $25.5 \%$ & Low & $25.0 \%$ \\
\hline None & $38.2 \%$ & None & $65.0 \%$ \\
\hline
\end{tabular}

5. Knowledge of the type of use or destination that is currently given to the sludge or bio-sludge generated in your city or municipality.

\begin{tabular}{cccc}
\hline Yes & $14.5 \%$ & Yes & $11.8 \%$ \\
\hline No & $72.7 \%$ & No & $55.5 \%$ \\
\hline More or less & $12.8 \%$ & More or less & $27.3 \%$ \\
\hline No opinion & $0.0 \%$ & No opinion & $5.4 \%$ \\
\hline
\end{tabular}

7. Perception level when information on biosolids use in agriculture was exposed

\begin{tabular}{cccc}
\hline Very positive & $62.7 \%$ & Yes, there is some risk & $27.3 \%$ \\
\hline Positive & $30.9 \%$ & There is no risk whatsoever & $13.6 \%$ \\
\hline Neutral & $5.5 \%$ & I do not know if there is a risk & $27.3 \%$ \\
\hline Negative & $0.9 \%$ & Need more information & $31.8 \%$ \\
\hline Strongly negative & $0.0 \%$ & & \\
\hline
\end{tabular}

9. Associations of activities in which they consider that biosolids can be used.

\begin{tabular}{|c|c|c|c|}
\hline As a fertilizer or compost & $79.1 \%$ & $\begin{array}{l}\text { As a product for use in } \\
\text { gardens, ornamental plants, } \\
\text { arborization, etc. }\end{array}$ & $39.1 \%$ \\
\hline $\begin{array}{l}\text { Direct use in agriculture } \\
\text { or soil }\end{array}$ & $78.2 \%$ & In energy recovery processes & $32.7 \%$ \\
\hline In forest plantations & $47.3 \%$ & $\begin{array}{l}\text { As an input in the } \\
\text { manufacture of } \\
\text { construction materials }\end{array}$ & $21.8 \%$ \\
\hline $\begin{array}{l}\text { Vegetation (green roof) } \\
\text { recovery, revegetation, landfill } \\
\text { landscaping, and quarry } \\
\text { restoration activities. }\end{array}$ & $41.8 \%$ & \multirow[t]{2}{*}{ In none of } & \multirow[t]{2}{*}{$0 \%$} \\
\hline $\begin{array}{l}\text { In green areas of graveyards, } \\
\text { road dividers, golf courses, } \\
\text { and vacant lots }\end{array}$ & $40.9 \%$ & & \\
\hline
\end{tabular}

4. Perception of the level of communication that WWTPs have in relation to sludge or bio-sludge treatment management.

6. Recognition of the activities in which biosolids can be used.

8. Perception of the existence or non-existence of any risk when growing food using biosolids. 
A

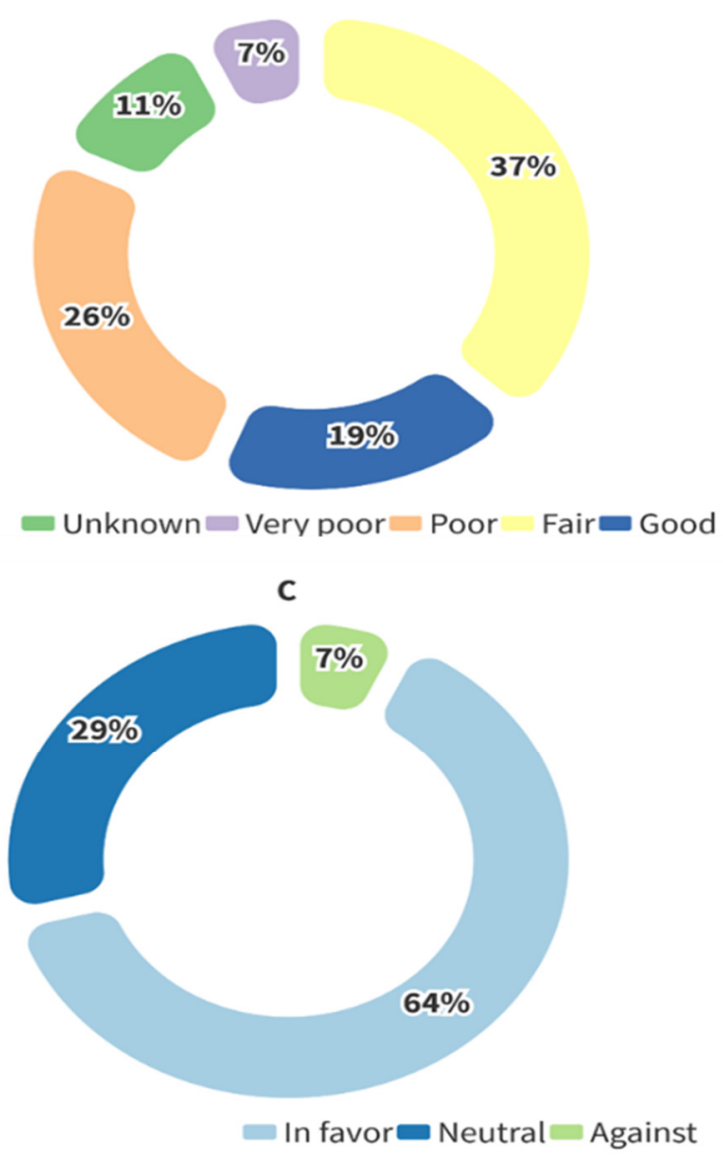

B

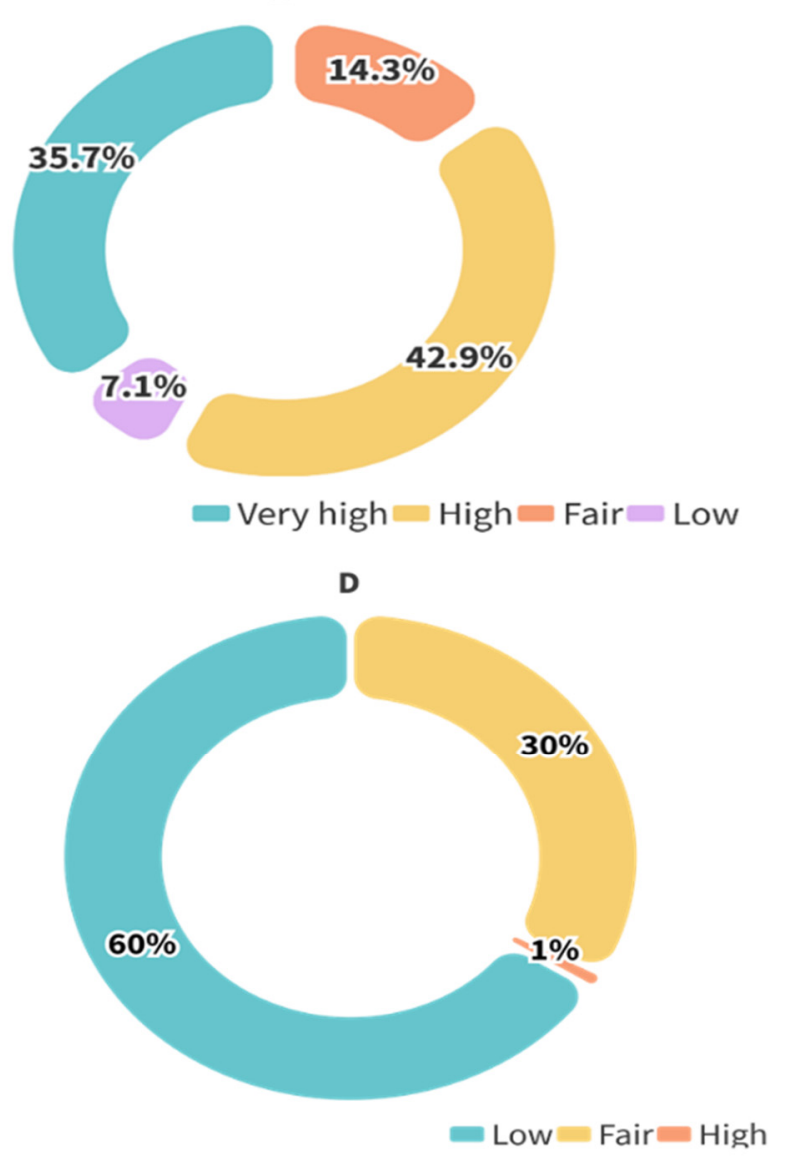

Figure 2. Results of the surveys conducted with the group of public and private entities. (A): Assessment of the current management of sludge and biosolids from WWTPs according to public and private actors, (B): level of interest in helping to improve sludge and biosolids management, $(\mathbf{C})$ : position of the organizations in relation to the use of biosolids in agriculture, (D): level of approach or work carried out by the institutions (or actors) to improve the perception of biosolids.

The different institutions or entities involved in the management and reuse of biosolids for agricultural purposes recognized that the four main challenges to achieve improved management and utilization are: (I) compliance with Decree 1287/2014 [33], (II) integration of the different actors (public/private) for the management and distribution of biosolids, (III) obtaining a Class A biosolid, and (IV) acceptance of biosolids use by farmers (Figure 3).

\subsection{Stakeholder Power and Influence}

Figures 4 and 5 show the distribution of each of the actors according to their level of authority (power) and their capacity to influence (influence) according to the systems in which they develop or operate. Through weighting, the actors were classified into the following four groups: (I) maintain satisfied, (II) maintain in proximity, (III) monitor, and (IV) maintain informed. In general, the distribution of the total number of stakeholders evaluated was heterogeneous since public, private, and non-affiliated entities are found in different quadrants. The location of the parties or players was also due to the characteristics and functions of each of the entities or groups evaluated (Appendix A-Table A1). 

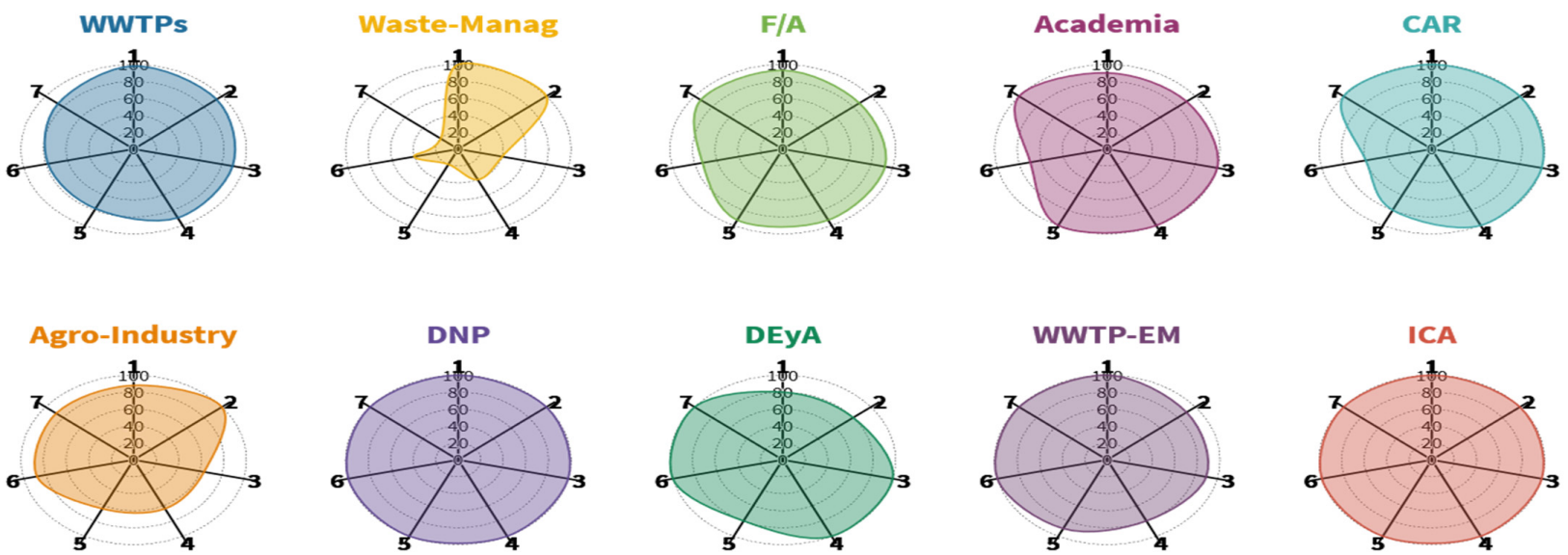

Figure 3. Challenges identified and valuation by each of the public and private sectors for the management and use of biosolids in agriculture. CAR: Regional Autonomous Corporation of Cundinamarca (Corporación Autónoma Regional de Cundinamarca), DEyA: economic and agricultural development area (Área de Desarrollo Económico y Agropecuario), DNP: National Planning Department (Departamento Nacional de Planeación), F/A: farmers or associations, ICA: Colombian Agricultural Institute (Instituto Colombiano Agropecuario), Waste-Manag: waste managers, WWTPs: wastewater treatment plants, and WWTP-EM: environmental manager of the WWTP. Challenge: 1: Compliance with Decree 1287/2014 [33]. 2: Obtaining a Class A biosolid. 3: Acceptance of the use of biosolids by farmers. 4: Acceptance of the use of biosolids in agriculture by the population. 5: The distribution and commercialization of biosolids. 6: Obtaining profits from the commercialization of biosolids. 7: Achieving the integration of different actors (public and private) for the management and distribution of biosolids.

As shown in Figure 4, the 17 stakeholders identified within the management system of the WWTP under study were distributed as follows: The "maintain close" group included the WWTP, a control entity of the Regional Autonomous Corporation of Cundinamarca (Corporación Autónoma Regional de Cundinamarca-CAR), Departmental Public Utility Company (Empresa Departamental de Servicios Públicos-ESPB), academia representatives, the environmental manager of the WWTP, and waste managers. Within the category of stakeholders to be "maintain satisfied" were two state entities, the Department of Housing (MinVivienda) and the Department of Environment and Sustainable Development (MinAmb), and the community. On the other hand, within the "monitoring" category was the agency in charge of economic development and agro-livestock (Economic and Agricultural Development Area (Área de Desarrollo Económico y Agropecuario-DEyA)) of the municipality in the study area, agro-industry, farmers and industry, and, finally, the control and surveillance entity of the Colombian Agricultural Institute (Instituto Colombiano Agropecuario-ICA). Lastly, the group including the public and two institutional entities-Superintendency of Domiciliary Public Utilities (Superintendencia de Servicios Públicos Domiciliarios-SSPD) and the National Planning Department (Departamento Nacional de Planeación-DNP)—were grouped under the category "maintain informed". 
Within the 17 stakeholders observed that would be involved in the system of biosolids utilization in agriculture, it was observed that 15 actors were concentrated in two groupings that corresponded to: "maintain close" and "maintain informed". In the case of the "maintain satisfied" category, only two groups of stakeholders were found-community and individuals. Lastly, for the "monitoring" group, no type of stakeholder was identified (Figure 5).

Subjects/Maintain satisfied

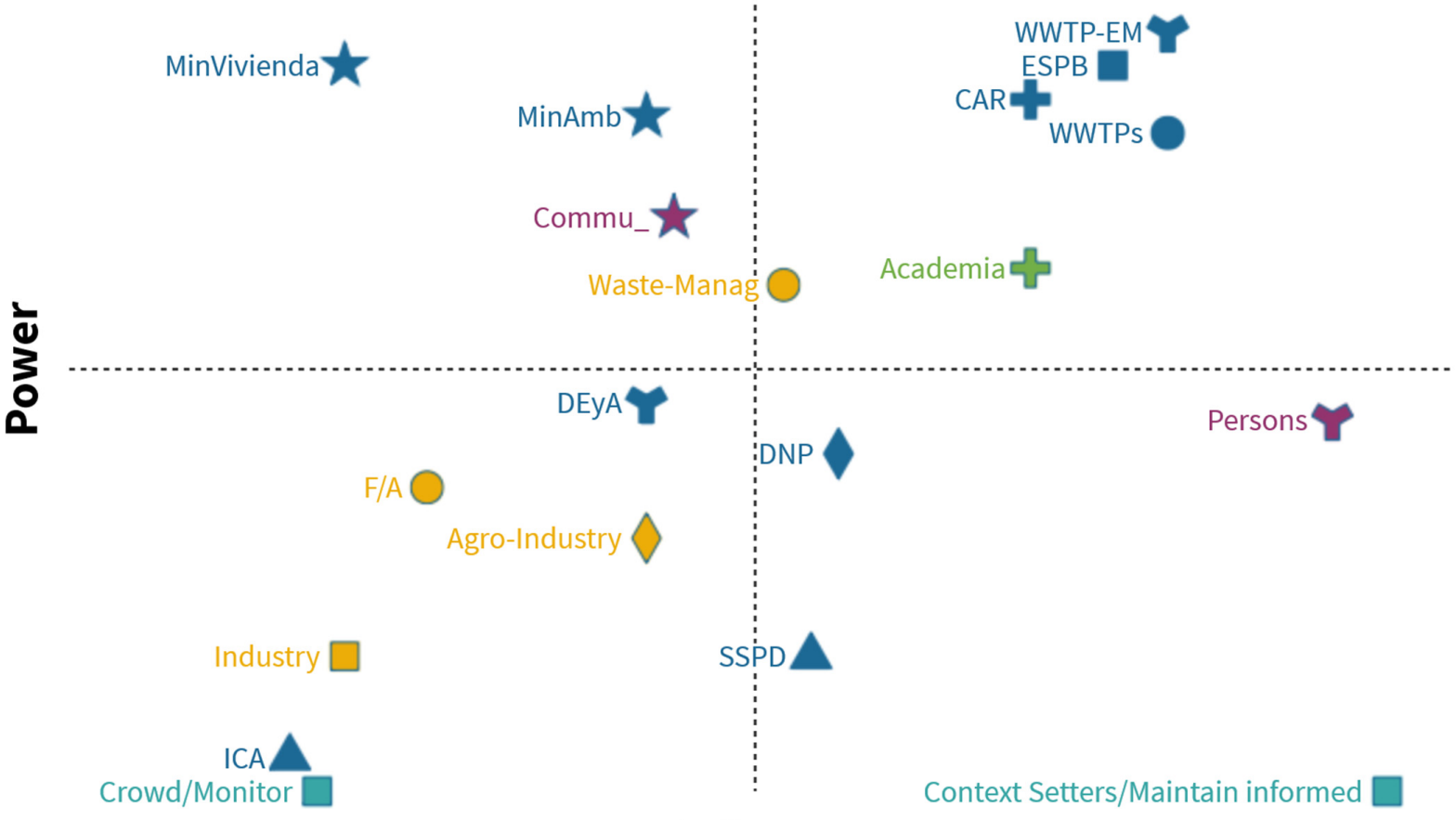

Influence

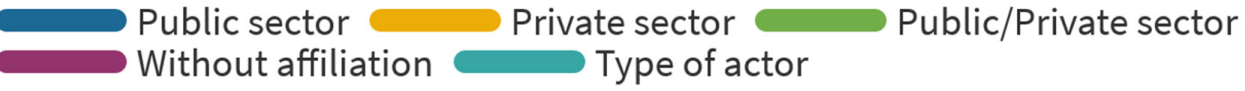

Figure 4. Power versus influence planes as attributes for stakeholders involved in the sludge and biosolids management system in Colombia. CAR: Regional Autonomous Corporation of Cundinamarca (Corporación Autónoma Regional de Cundinamarca); Commu_: community; DEyA: economic and agricultural development area (Área de Desarrollo Económico y Agropecuario); DNP: National Planning Department (Departamento Nacional de Planeación); ESPB: Departmental Public Utility Company (Empresa Departamental de Servicios Públicos); F/A: farmers or associations; ICA: Colombian Agricultural Institute (Instituto Colombiano Agropecuario); MinAmb: Department of Environment and Sustainable Development (Ministerio de Ambiente y Desarrollo Sostenible); MinVivienda: Department of Housing, City, and Territory (Ministerio de Vivienda, Ciudad y Territorio); SSPD: Superintendency of Domiciliary Public Utilities (Superintendencia de Servicios Públicos Domiciliarios); Waste-Manag: waste managers; WWTPs: wastewater treatment plants; and WWTP-EM: environmental manager of the WWTP. 


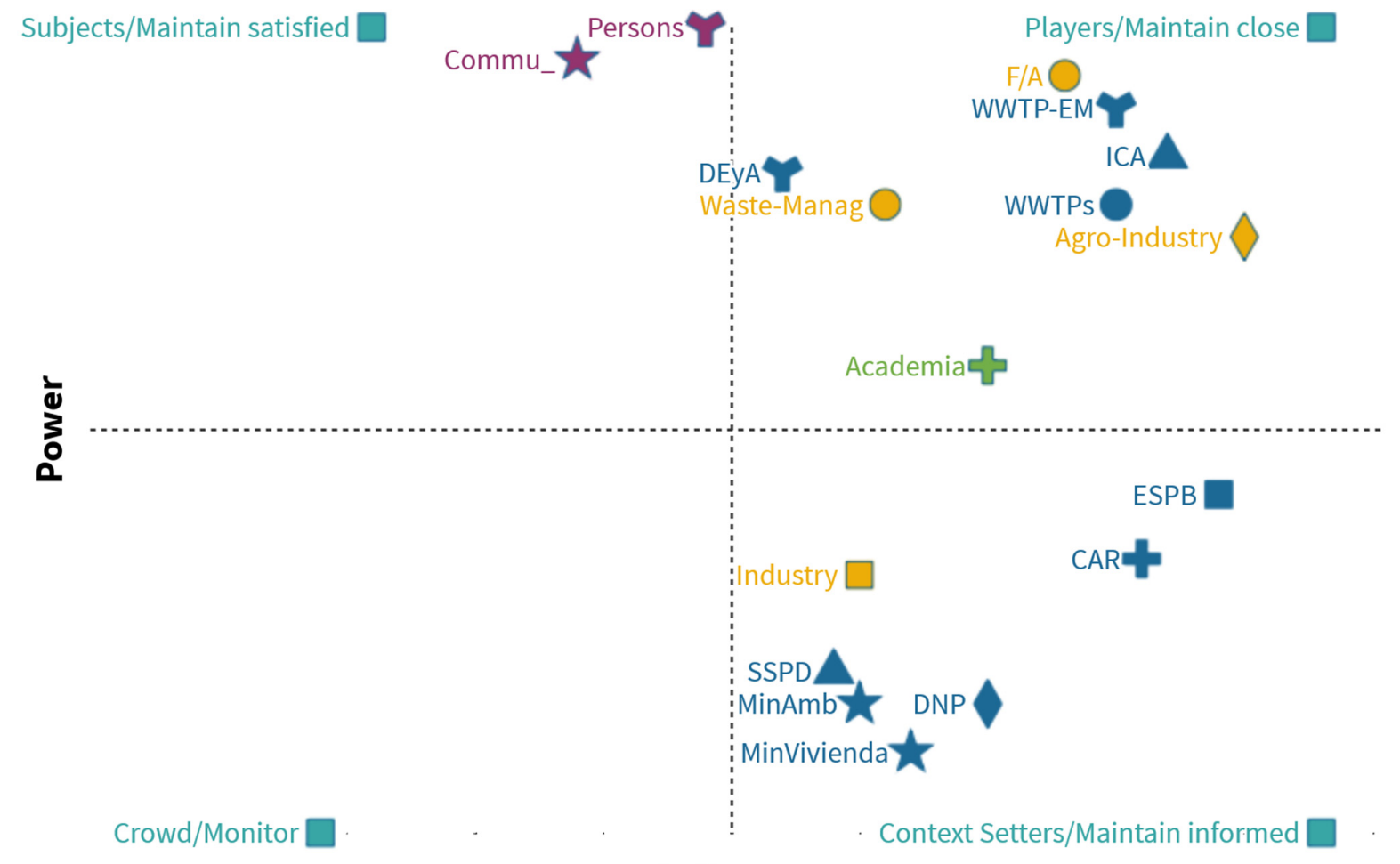

Influence

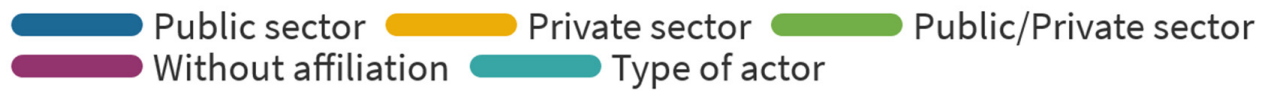

Figure 5. Power versus influence diagram as an attribute for the parties that would be projected to participate in the use of biosolids in agriculture in Colombia. CAR: Regional Autonomous Corporation of Cundinamarca (Corporación Autónoma Regional de Cundinamarca); Commu_: community; DEyA: economic and agricultural development area (Área de Desarrollo Económico y Agropecuario); DNP: National Planning Department (Departamento Nacional de Planeación); ESPB: Departmental Public Utility Company (Empresa Departamental de Servicios Públicos); F/A: farmers or associations; ICA: Colombian Agricultural Institute (Instituto Colombiano Agropecuario); MinAmb: Department of Environment and Sustainable Development (Ministerio de Ambiente y Desarrollo Sostenible); MinVivienda: Department of Housing, City, and Territory (Ministerio de Vivienda, Ciudad y Territorio); SSPD: Superintendency of Domiciliary Public Utilities (Superintendencia de Servicios Públicos Domiciliarios); Waste-Manag: waste managers; WWTPs: wastewater treatment plants; and WWTP-EM: environmental manager of the WWTP.

\section{Discussion}

\subsection{SWOT and TOWS Strategies}

Adopting public policies for the reuse of by-products generated from wastewater treatment brings benefits to producers, to the people who use them, and to the area that allows their use, as well as allowing WWTPs to be projected as sustainable entities in the future. However, according to the results obtained from the SWOT analysis applied to sludge and biosolids regulations in Colombia (Table 3), the aspects identified for strengthening are: monitoring of emerging contaminants, application of efficiency indicators for biosolids stabilization processes, guidelines for monitoring and use of biosolids, reporting of updated information in unified platforms (UIS), and access to these as an input for continuous improvement and decision making, as has been considered in other Latin American [91-95] and European countries $[5,12,96]$ that favor their use in the agricultural sector. These factors influence and limit the adequate management and use of biosolids in agriculture; therefore, they are essential variables to take into account in the Colombian regulations.

Regarding the management performed by the WWTP evaluated (Table 4), the following was evidenced: (I) the lack of knowledge of the type of sludge generated, (II) the 
low efficiency of the stabilization process carried out at the plant, (III) equipment out of service since 2019 or currently operated manually, (IV) the non-inclusion of current sludge management in internal reports, $(\mathrm{V})$ the absence of a sludge stabilization procedure that includes monitoring of control variables ( $\mathrm{pH}$, temperature), and (VI) failure to report the amount of sludge or biosolids generated to the open information system (UIS) intended for this purpose. All these factors hinder proper management and the possible use of biosolids in agriculture and coincide with the low interest reported in some developing countries or in areas where sludge or biosolids management is low due to technical, operational, economic, and infrastructure limitations $[5,29,30]$.

Considering that solid waste management presents various barriers and risks that weaken the implementation process and utilization practices, the application of the SWOT analysis becomes a factor to be considered for the improvement of the different processes [53,97]. The weaknesses and threats identified in this study from the SWOT analysis are similar to those obtained in other related studies, such as low cooperation and a lack of information, training, communication, and an approach towards an integrated system for waste management, as well as weaknesses in the operation or stabilization systems, lack of public awareness of the importance and usefulness of the biosolids generated, lack of support from the local government, and lack of partnerships between public and private entities [98-103].

The strategies proposed in this study for strengthening sludge and biosolids regulations (Table 5), and in the particular case of the WWTP evaluated (Table 6), will make it possible to strengthen the use of organic waste in the agricultural sector, as has been done in other countries [53,97,104,105]; develop organizational improvement [106-109] through the creation of value chains; increase the government response capacity and promote the democratic process in decision making related to the area; and encourage the adoption or expansion of an institutional policy that will allow the definition of objectives for the treatment and use of biosolids, thus strengthening the efforts towards the same end $[53,108,110]$, since, in most cases, the objectives are focused mainly on water management.

\subsection{Public Surveys and Surveys of Public and Private Entities}

The results obtained from the surveys $(\mathrm{n}=178)$, in which people were asked about their knowledge of the concept of sludge and biosolids, showed that there is some degree of lack of knowledge regarding these two types of waste (34.7-38.6\%), this may be due to the fact that people perceive that there is no or little information about the internal management currently carried out by the WWTPs for the treatment of wastewater $(63.7 \%)$ and sludge and biosolids (90\%) (Table 7). According to Beecher et al. [64], only $42 \%$ of their respondents recognized they have heard the term biosolids and of these, only $11 \%$ defined it accurately, while $48 \%$ had an incorrect definition or did not know and $1 \%$ associated it with the same sludge term.

Of the total number of people surveyed in this study, $61.4 \%$ claimed to know, in some way, what a biosolid was, and most people recognized and most frequently associated reusing biosolids as fertilizers and their direct application in agriculture (Table 7), which coincides with the forms of reuse described in Decree 1287 of 2014 [33]. In total, 93.6\% of people and $64 \%$ of public and private entities or organizations had a positive attitude towards the use of these wastes in agriculture, while $0.9 \%$ of people and $7 \%$ of organizations disagreed (Table 7 and Figure 2C). Of those surveyed, 13.6\% of the people considered that carrying out this practice does not suppose any type of risk, while $27.3 \%$ stated that they did consider there to be a risk and $31.8 \%$ recognized they needed more information on the subject or did not know (27.3\%) if there is any type of risk (Table 7).

According to Beecher et al. [64], Robinson et al. [111], and Novanda et al. [112], people have a positive attitude towards the reuse of biosolids through direct application to the soil or as fertilizers, however, this acceptance decreases as the application site is closer to their place of residence [111], as is the case of farmers who have a negative perception towards the use and application of biosolids in the soil $[64,66,113]$, but in some cases there may be 
some degree of acceptance with certain limitations [21]. However, this type of situation or the level of risk perception may decrease as communication and education increase [64].

\subsection{Stakeholder Analysis, Weighting}

Figures 4 and 5 show a heterogeneous distribution of the 16 actors in each of the evaluated systems. This distribution could allow the intervention and work of different parties or institutions directly and indirectly, both in the management and in the use of biosolids in agriculture. The achievement of a management system with the presence and action of various actors would diversify the decision-making process, favoring its approach [76], compared to a system with a low presence and distribution of players. On the other hand, in addition to having players with a high level of power and influence located in the "maintain close and satisfied" groups, the importance of establishing effective information mechanisms for the other two groups should be emphasized, with special attention to the parties with low power but high influence characteristics, since they could become opponents of system development and change, as they can be considered players with potential characteristics for change, action, and conversion to key players $[68,114]$.

The players with technical and academic knowledge (waste managers, agro-industry, farmers, control entities, and universities) located and characterized with high power and influence can transmit in both systems (Figures 4 and 5) the knowledge and experiences to the other parties that may present a lower degree of information and technical skills. In addition, the presence of these agents prevents a system from having weaknesses or gaps, thus facilitating the decision-making process that allows the improvement and utilization of waste $[75,76]$.

The positions in the "maintain informed" and "monitor" groups held by some of the players in this study will require a high level of work, communication, training, and an approach to the system to strengthen the level of power and influence, allowing them to become key players in the future. The active participation of various parties will improve understanding and changes in the system, taking into account the challenges and barriers presented by both waste management and utilization. Therefore, it is necessary to work on the development of these groups, although it is sometimes described that the high level of effort made by these groups is not comparable with the achievements or benefits obtained [114] or that they may behave intermittently, discontinuously, or in isolation [67].

Achieving the implementation of the strategies described in Tables 5 and 6 and the evolution of both systems is not only achieved through the identification and weighting of players and the formulation of various strategies, but also requires that all players carry out their implementation in coordination with other entities and communities. For example, for the WWTPs of the main cities with greater experience in the management and use of biosolids, public and private entities should accompany the municipal actors to strengthen the prioritization of actions, formulation and fulfillment of objectives, and approval and mobilization of necessary resources in an efficient manner [53,76].

In biosolids management, it has been possible to identify opportunities for change and achievements related to the participation or association of individual and group players and communities resistant to the use and application of this type of waste $[13,64]$. It is important to highlight the opportunity that exists to improve the management and quality of biosolids at the national level through the participation and support of different organizations (Figure 2B), in spite of the scarce relation these entities have had to improve the perception of biosolids (Figure 2D).

\subsection{Analysis of the Evaluation Methods Used and Identified Stakeholders}

The use of the SWOT tool in the analysis of the current management of the WWTP studied, as well as of the regulations, made it possible to identify and establish the challenges that should be met to improve its condition; however, its use has a series of limitations and it was necessary to use and combine other methodologies, as has been identified in other studies $[59,60]$. The SWOT did not allow us to evaluate the approach and effectiveness of 
each of the strategies proposed, nor did it allowed us to contrast the positions of favorability, disagreement, or neutrality of the different actors and institutions identified in this study.

On the other hand, among the limitations identified in the SWOT methodology, it was found that the analysis was carried out through a current or general context, which makes it difficult to evaluate and analyze future scenarios, taking into account that waste management and utilization can be considered as a system with constant changes and challenges, and even more so in Colombia, where there is no agricultural utilization of any kind. Nevertheless, the aspects identified from the weaknesses, opportunities, strengths, and threats become a valuable input within the analysis carried out, which can provide sufficient information for other types of complementary methodologies and strategies for other areas that may present similar conditions [53,104,115-117].

With regard to the evaluation of the power and influence of each actor, it is important to mention that this methodology does not take into account the level or capacity of an agent to create networks or work associations, which can become key players and disseminators of information regardless of their categorization of power/influence. Likewise, this methodology does not take into account the power relations of one player over another, either directly or through a third party.

On the other hand, it is important to mention that the work, organization, and level of communication between the interested parties identified in this study are aspects to be considered, and potentially recognized as limitations. Policies, regulations, and administrative or bureaucratic processes negatively affect transformation, management, and organization processes between actors. This results in exhausted inclusion mechanisms and formulation of policy that strengthen the conversion to "ecologically sustainable" entities.

At the municipal level, the limitations of the WWTP studied were mainly economic. This was the case in the allocation of economic resources to the management of sludge and biosolids; improvement, updating, and maintenance of the equipment of the sludge line; as well as the absence of involvement or integration with the community. On the other hand, the rotation of the operating personnel, as well as of the administration of the wastewater treatment plant (WWTP), resulted in trained personnel being unable to continue with the operation or the transfer of information being affected. The perception of rivers and effluents being of low quality, in addition to poor communication and rapport with the community, resulted in the WWTP being deemed nonessential within the process of treating wastewater and generated by-products. The sum of these factors become elements to consider for the decision-making parties.

\section{Conclusions}

According to the results of the SWOT analysis, we recommend the development of strategies that would allow the strengthening of regulations and the improvement of sludge and biosolids management at the WWTP across five strategic lines: (I) integration and partnership between different public-private institutions; (II) greater dissemination of sludge and biosolids management through documentation and provision of information; (III) allocation of economic and technical resources for the improvement, control, and monitoring of the stabilization process currently carried out at the WWTP; (IV) actualization of the public sewage service tariff, including the costs of treatment and stabilization; and (V) creation of guidelines for the management and use of biosolids.

Although the people surveyed perceived low communication from the WWTPs regarding the management of sludge and biosolids $(72.7 \%), 61.4 \%$ and $65.3 \%$ of the respondents were clear about the concept of biosolids and sludge, respectively. Likewise, $93.6 \%$ of those surveyed expressed acceptance for biosolids to be used in agriculture; however, $27.3 \%$ of the population perceived a risk in carrying out this type of practice or form of use, and $31.8 \%$ considered that they needed more information on the subject.

It is important to highlight the high interest (78.6\%) of public and private entities in participating in the improvement of biosolids management, as well as the perception between 
fair $(37 \%)$ and poor $(26 \%)$ that public and private entities have about the management carried out by WWTPs in Colombia.

The identification and weighting of stakeholders made it possible to determine the series of entities that should be worked with on a permanent, regular, or occasional basis, as well as the recognition of groups that had not been taken into account and that could play a key role directly and indirectly (Economic and Agricultural Development AreaDEyA, neighboring communities, individuals, waste managers, farmers, and industry representatives), thus favoring positive change.

It is important to continue evaluating the biosolids management and utilization system under complementary methodologies that allow, through future scenarios, the identification and evaluation of determinants that influence management and reuse systems, as well as the evaluation and analysis of the positions of the actors and their ability to generate networks among the different actors.

It is necessary to evaluate biosolids as a potential element in the production cycle and their role within the business model, in future studies, to evaluate them as an element in the circular economy of the agricultural sector.

Author Contributions: C.V., A.C.S.-A. and F.-J.V. participated in the search and collection of information. C.V. and F.-J.V. consolidated, tabulated, and analyzed the data. C.V. drafted the manuscript. A.C.S.-A., C.C., F.-J.V. and M.G.M. reviewed, adjusted, and co-edited the document. C.C. attained financial support. C.V. and M.G.M. carried out the conception of the study. M.G.M. conducted the direction of the study. All authors have read and agreed to the published version of the manuscript.

Funding: This research and publication were funded by Pontificia Universidad Javeriana, Bogotá, Colombia. Grant numbers 20078-005874-009872.

Data Availability Statement: Not applicable.

Acknowledgments: The authors thank the different public and private entities and each of the people who participated in the surveys and interviews conducted during the period 2020-2021. They are also grateful for the information and documentation provided by the WWTP of the study site and other entities.

Conflicts of Interest: The authors declare no conflict of interest.

\section{Appendix A}

Table A1. Roles of institutions and stakeholders involved in the management and use of biosolids for agriculture.

\begin{tabular}{|c|c|c|}
\hline Stakeholders $(n=28)$ & Operating Level & Associated Functions \\
\hline $\mathrm{DNP}(\mathrm{n}=1)[118]$ & $\mathrm{N}$ & $\begin{array}{c}\text { "To design, guide and evaluate Colombian public policies, the management and } \\
\text { allocation of public investment and the implementation of these in plans, } \\
\text { programs and projects of the government in the social, economic and } \\
\text { environmental fields." }\end{array}$ \\
\hline MinAmb [119] & $\mathrm{N}$ & $\begin{array}{c}\text { "To design and regulate public policies and general conditions for environmental } \\
\text { sanitation..... to prevent, repress, eliminate or mitigate the impact of polluting, } \\
\text { deteriorating or destructive activities on the environment or natural heritage, in } \\
\text { all economic and productive sectors." }\end{array}$ \\
\hline MinVivienda [120] & $\mathrm{N}$ & $\begin{array}{l}\text { "Define feasibility and eligibility criteria for water, sewerage and sanitation } \\
\text { projects and approve them, and provide technical assistance to territorial entities, } \\
\text { environmental authorities and public utility service providers." }\end{array}$ \\
\hline CAR $(n=1)$ [121] & $\mathrm{N}$ & $\begin{array}{l}\text { "Maximum environmental authority in accordance with the criteria and } \\
\text { guidelines established by the Ministry of Environment and } \\
\text { sustainable development." } \\
\text { "Promote and develop community participation in activities and programs for } \\
\text { environmental protection, sustainable development and adequate management of } \\
\text { renewable natural resources." }\end{array}$ \\
\hline
\end{tabular}


Table A1. Cont.

\begin{tabular}{|c|c|c|}
\hline Stakeholders $(\mathrm{n}=\mathbf{2 8})$ & Operating Level & Associated Functions \\
\hline $\operatorname{ICA}(n=1)[122]$ & $\mathrm{N}$ & $\begin{array}{c}\text { "Exercise technical control over the production, importation and } \\
\text { commercialization of agricultural inputs to prevent risks that may affect } \\
\text { agricultural health." }\end{array}$ \\
\hline WWTPs $(n=12)$ & $\mathrm{CM}$ & $\begin{array}{c}\text { "Guarantee to the community the treatment of wastewater in the coverage area } \\
\text { to reduce the environmental impact, through the correct operation of the WWTP } \\
\text { and maintenance of its components." }\end{array}$ \\
\hline Waste-Manag $(\mathrm{n}=2)$ & $\mathrm{N}$ & Collect organic waste to be treated or disposed of correctly. \\
\hline Agro-Industry $(\mathrm{n}=2)$ & $\mathrm{N}$ & $\begin{array}{l}\text { To provide economic income and support to the farmers. } \\
\text { Reduce post-harvest losses in agricultural production. } \\
\text { Develop new forms of production. }\end{array}$ \\
\hline $\mathrm{F} / \mathrm{A}(\mathrm{n}=4)$ & $\mathrm{N}$ & $\begin{array}{l}\text { Maintain agricultural activities and the development of the national and } \\
\text { local economy. }\end{array}$ \\
\hline Academia $(\mathrm{n}=2)$ & $\mathrm{CM}$ & $\begin{array}{l}\text { Integrate research, academia, and social projection from teaching, } \\
\text { education, and service. }\end{array}$ \\
\hline WWTP-EM (n = 2) [123] & M & $\begin{array}{c}\text { "Establish and implement actions aimed at directing the environmental } \\
\text { management of the company operating the WWTP; ensure compliance with } \\
\text { environmental standards; promote cleaner production practices and the rational } \\
\text { use of natural resources." }\end{array}$ \\
\hline DEyA $(n=1)[124]$ & M & $\begin{array}{l}\text { "Define programs for entrepreneurship and agricultural development, providing } \\
\text { technical assistance to all the agents involved, adopting and directing the plans } \\
\text { that the municipality needs to advance for the development of this sector, } \\
\text { especially the farming sector." } \\
\text { "Promote community participation and the social improvement of the } \\
\text { agricultural activity of the residents of the municipality, taking into account the } \\
\text { mechanisms of citizen participation and the needs of the community." }\end{array}$ \\
\hline ESPB [125] & $\mathrm{D}$ & $\begin{array}{c}\text { "Manage the provision and strengthening of public services in the department } \\
\text { of Boyaca, providing support, advice and technical assistance at the municipal } \\
\text { and regional levels." }\end{array}$ \\
\hline SSPD [126] & $\mathrm{N}$ & $\begin{array}{c}\text { "To monitor, inspect and control compliance by the supervised parties with the } \\
\text { provisions that regulate the proper rendering of residential public utilities and } \\
\text { the protection of users." }\end{array}$ \\
\hline
\end{tabular}

CAR: Regional Autonomous Corporation of Cundinamarca (Corporación Autónoma Regional de Cundinamarca); CM: cities and municipalities; D: departmental; DEyA: economic and agricultural development area (Área de Desarrollo Económico y Agropecuario); DNP: National Planning Department (Departamento Nacional de Planeación); ESPB: Departmental Public Utility Company (Empresa Departamental de Servicios Públicos); F/A: farmers or associations; ICA: Colombian Agricultural Institute (Instituto Colombiano Agropecuario); M: municipal; MinAmb: Department of Environment and Sustainable Development (Ministerio de Ambiente y Desarrollo Sostenible); MinVivienda: Department of Housing, City, and Territory (Ministerio de Vivienda, Ciudad y Territorio); SSPD: Superintendency of Domiciliary Public Utilities (Superintendencia de Servicios Públicos Domiciliarios); Waste-Manag: waste managers; WWTPs: wastewater treatment plants; and WWTP-EM: environmental manager of the WWTP.

\section{References}

1. Jones, E.R.; van Vliet, M.T.H.; Qadir, M.; Bierkens, M.F.P. Country-level and gridded estimates of wastewater production, collection, treatment and reuse. Earth Syst. Sci. Data 2021, 13, 237-254. [CrossRef]

2. SSPD. Estudio Sectorial de los Servicios Públicos Domiciliarios de Acueducto y Alcantarillado-2019; Superintendencia de Servicios Públicos Domiciliarios: Bogotá, Colombia, 2020; pp. 1-64.

3. DNP. Estrategia Para la Implementación de los Objetivos de Desarrollo Sostenible (ODS) en Colombia, CONPES 3918; Departamento Nacional de Planeación: Bogotá, Colombia, 2018; pp. 1-74.

4. SSPD. Estudio Sectorial de los Servicios Públicos Domiciliarios de Acueducto y Alcantarillado 2014-2017; Superintendencia de Servicios Públicos Domiciliarios: Bogotá, Colombia, 2018; pp. 1-88.

5. Wiśniowska, E.; Grobelak, A.; Kokot, P.; Kacprzak, M. Sludge legislation-comparison between different countries. In Industrial and Municipal Sludge: Emerging Concerns and Scope for Resource Recovery; Elsevier: Amsterdam, The Netherlands, 2019 ; pp. $201-224$. ISBN 9780128159071.

6. Margot, J.; Rossi, L.; Barry, D.A.; Holliger, C. A review of the fate of micropollutants in wastewater treatment plants. Wiley Interdiscip. Rev. Water 2015, 2, 457-487. [CrossRef] 
7. Chávez Porras, Á.; Velásquez Castiblanco, Y.L.; Casallas Ortega, N.D. Características físico-químicas de humus obtenido de biosólidos provenientes de procesos de tratamiento de aguas residuales. Inf. Tec. 2017, 81, 122. [CrossRef]

8. Eriksson, E.; Christensen, N.; Ejbye Schmidt, J.; Ledin, A. Potential priority pollutants in sewage sludge. Desalination 2008, 226, 371-388. [CrossRef]

9. Viau, E.; Bibby, K.; Paez-Rubio, T.; Peccia, J. Toward a consensus view on the infectious risks associated with land application of sewage sludge. Environ. Sci. Technol. 2011, 45, 5459-5469. [CrossRef] [PubMed]

10. Mihelcic, J.R. Sludge management: Biosolids and fecal sludge. In Water and Sanitation for the 21st Century: Health and Microbiological Aspects of Excreta and Wastewater Management (Global Water Pathogen Project); Mihelcic, J.R., Ed.; UNESCO: Paris, France, 2018.

11. Basic Information about Biosolids. Available online: https:/ /www.epa.gov/biosolids/basic-information-about-biosolids (accessed on 24 February 2021).

12. Collivignarelli, M.; Abbà, A.; Frattarola, A.; Carnevale Miino, M.; Padovani, S.; Katsoyiannis, I.; Torretta, V. Legislation for the reuse of biosolids on agricultural land in Europe: Overview. Sustainability 2019, 11, 6015. [CrossRef]

13. Pepper, I.L.; Zerzghi, H.; Brooks, J.P.; Gerba, C.P. Sustainability of land application of class B biosolids. J. Environ. Qual. 2008, 37, S58-S67. [CrossRef] [PubMed]

14. Eurostat Sewage Sludge Production and Disposal from Urban Wastewater. Available online: https:/ / ec.europa.eu/eurostat/ web/environment/water (accessed on 14 November 2020).

15. Zhang, W.; Alvarez-Gaitan, J.; Dastyar, W.; Saint, C.; Zhao, M.; Short, M. Value-added products derived from waste activated sludge: A biorefinery perspective. Water 2018, 10, 545. [CrossRef]

16. Collard, M.; Teychené, B.; Lemée, L. Comparison of three different wastewater sludge and their respective drying processes: Solar, thermal and reed beds-Impact on organic matter characteristics. J. Environ. Manag. 2017, 203, 760-767. [CrossRef]

17. Teoh, S.K.; Li, L.Y. Feasibility of alternative sewage sludge treatment methods from a lifecycle assessment (LCA) perspective. J. Clean. Prod. 2020, 247, 119495. [CrossRef]

18. Lu, Q.; He, Z.L.; Stoffella, P.J. land application of biosolids in the USA: A review. Appl. Environ. Soil Sci. 2012, $2012,201462$. [CrossRef]

19. Sharma, B.; Sarkar, A.; Singh, P.; Singh, R.P. Agricultural utilization of biosolids: A review on potential effects on soil and plant grown. J. Waste Manag. 2017, 64, 117-132. [CrossRef]

20. Laura, F.; Tamara, A.; Müller, A.; Hiroshan, H.; Christina, D.; Serena, C. Selecting sustainable sewage sludge reuse options through a systematic assessment framework: Methodology and case study in Latin America. J. Clean. Prod. 2020, $242,118389$. [CrossRef]

21. Wood, M.D.; Thorne, S.; Kovacs, D.; Butte, G.; Linkov, I.; Eggers, S.; Thorne, S. Conducting effective outreach with community stakeholders about biosolids: A customized strategic Risk Communications Process ${ }^{\mathrm{tm}}$ based on mental modeling. In Mental Modeling Approach; Springer: New York, NY, USA, 2017; pp. 153-177. ISBN 978-1-4939-6616-5.

22. Axelrad, G.; Gershfeld, T.; Feinerman, E. Reclamation of sewage sludge for use in Israeli agriculture: Economic, environmental and organizational aspects. J. Environ. Plan. Manag. 2013, 56, 1419-1448. [CrossRef]

23. Bertanza, G.; Baroni, P.; Canato, M. Ranking sewage sludge management strategies by means of decision support systems: A case study. Resour. Conserv. Recycl. 2016, 110, 1-15. [CrossRef]

24. WWAP. The United Nations World Water Development Report 2017. Wastewater: The Untapped Resource; UNESCO: Paris, France, 2017; pp. $1-180$.

25. Gutiérrez-Rosero, J.A.; Ramírez-Fajardo, Á.I.; Rivas, R.; Linares, B.; Paredes, D. Tratamiento de lodos generados en el proceso convencional de potabilización de agua. Revista Ingenierías Universidad de Medellín 2014, 13, 13-27. [CrossRef]

26. Vélez Zuluaga, J.A. Los biosólidos: ¿Una solución o un problema? Producción Mas Limpia 2007, 2, 57-71.

27. Melo Cerón, A.R.; Rodríguez González, A.; González Guzmán, J.M. Manejo de biosólidos y su posible aplicación al suelo, caso Colombia y Uruguay. RIAA 2017, 8, 217-226. [CrossRef]

28. Spinosa, L. Wastewater Sludge: A Global Overview of the Current Status and Future Prospects, 2nd ed.; IWA Publishing: London, UK, 2011; Volume 10, ISBN 9781780401195.

29. Spinosa, L. Status and Perspectives of Sludge Management; IWA Publishing: London, UK, 2007; pp. 103-108.

30. Jiménez, B.; Drechsel, P.; Koné, D.; Bahri, A.; Raschid-Sally, L.; Qadir, M. Wastewater, sludge and excreta use in developing countries: An overview. In Wastewater Irrigation and Health: Assessing and Mitigating Risk in Low-Income Countries; Bahri, A., Drechsel, P., Raschid-Sally, L., Redwood, M., Eds.; International Water Management Institute (IWMI); Earthscan; International Development Research Centre (IDRC): London, UK, 2010; pp. 3-27. ISBN 9781849774666.

31. Venegas, C. Aprovechamiento de los Biosólidos para la Agricultura a través del Fortalecimiento de Estrategias de Gestión Ambiental para un Municipio de Boyacá, Colombia. Master's Thesis, Pontificia Universidad Javeriana, Bogotá, Colombia, 2021.

32. Dáguer, G.P. Gestión de biosólidos en Colombia. Rev. ACODAL 2003, 8, 1-7.

33. MinVivienda. Decreto 1287. Se establecen Criterios para el Uso de los Biosólidos Generados en Plantas de Tratamiento de Aguas Residuales Municipales en el Territorio de Colombia; Ministerio de Vivienda, Ciudad y Territorio: Bogotá, Colombia, 2014; pp. 1-15.

34. Hurtado, R.; Nolasco, D. Managing Wastewater as a Resource in Latin America and the Caribbean Towards a Circular Economy Approach. 2017, pp. 1-28. Available online: https://programme.worldwaterweek.org/Content/ProposalResources/allfile/ managing_wastewater_as_a_resource_in_lac.pdf (accessed on 30 September 2021).

35. Aguas Andinas. Reporte de Sostenibilidad Pura Vida 2013; Aguas Andinas: Santiago, Chile, 2014; pp. 1-132. 
36. Rosales, E.P. Aplicación benéfica de biosólidos en Chile: Desafíos, dificultades y oportunidades de mejora. Rev. AIDS Chile 2018, $14,18-23$.

37. Bittencourt, S. Agricultural use of sewage sludge in Paraná State, Brazil: A decade of national regulation. Recycling 2018, 3, 53. [CrossRef]

38. EMPAS. Empresa Pública de Alcantarillado de Santander S.A. E.S.P. In Informe de Gestión; Santander, Colombia, 2019; pp. 1-169. Available online: https:/ /www.empas.gov.co/wp-content/uploads/2020/07/1-Informe-de-Gesti\%C3\%B3n-2019.pdf (accessed on 30 September 2021).

39. Air and Soil Care, an EPM Contribution for the Health of the Earth. Available online: https://www.epm.com.co/site/cuidadodel-aire-y-de-los-suelos-un-aporte-de-epm-por-la-salud-de-la-tierra (accessed on 8 January 2021).

40. WWTP of EPM (Medellín, Colombia); WWTPs of El Salitre (Bogotá, Colombia); WTTP of EMCALI (Cali, Colombia); WTTP of EMPAS (Santander, Colombia); WTTP of La Calera (La Calera-Cundinamarca, Colombia); WWTP of El Santuario (PidecuestanaSantander, Colombia); WWTP of EPA (Armenia-Quindío, Colombia); WTTP of IBAL (Ibagué-Tolima, Colombia); WTTP of Guamal (Villavicencio-Meta, Colombia). Personal communication. 2021.

41. Montoya, G.G.; Gómez, C.X.R. Acondicionadores de Suelo y fertilizantes a partir de biosólidos generados en plantas de tratamiento de aguas residuales de EPM. Rev. EPM 2019, 11-21. Available online: https://www.epm.com.co/site/Portals/0/ PDF/Revista_EPM_No_13_2019.pdf?ver=2019-07-26-105718-273 (accessed on 30 September 2021).

42. Política de Crecimiento Verde. Available online: https://www.dnp.gov.co/Crecimiento-Verde/Paginas/Politica-crecimientoverde.aspx (accessed on 13 January 2021).

43. DNP. Economía Circular en la Gestión de los Servicios de Agua Potable y Manejo de Aguas Residuales, CONPES 4004; Departamento Nacional de Planeación: Bogotáa, Colombia, 2020; pp. 1-64.

44. DNP. Bases Del Plan Nacional de Desarrollo 2018-2022. Pacto por Colombia, Pacto por la Equidad; Departamento Nacional de Planeación: Bogotáa, Colombia, 2019; pp. 1-1457.

45. MinAmbiente. Resolución 1207 de 2014 Por la cual se Adoptan Disposiciones Relacionadas con el Uso de Aguas Residuales Tratadas; Ministerio de Ambiente y Desarrollo Sostenible: Bogotá, Colombia, 2014; pp. 1-9.

46. Documentos Consejo Nacional de Política Económica y Social (CONPES). Available online: https://www.dnp.gov.co/CONPES/ documentos-conpes/Paginas/documentos-conpes.aspx (accessed on 24 June 2021).

47. Colombia: Global Leader in Agriculture. Available online: http://www.relocationsrs.com.co/colombia-world-agriculturalpantry/ (accessed on 21 February 2021).

48. Troschinetz, A.M.; Mihelcic, J.R. Sustainable recycling of municipal solid waste in developing countries. J. Waste Manag. 2009, 29, 915-923. [CrossRef] [PubMed]

49. Tai, J.; Zhang, W.; Che, Y.; Feng, D. Municipal solid waste source-separated collection in China: A comparative analysis. J. Waste Manag. 2011, 31, 1673-1682. [CrossRef] [PubMed]

50. di Bella, V.; Ali, M.; Vaccari, M. Constraints to healthcare waste treatment in low-income countries-A case study from Somaliland. Waste Manag. Res. 2012, 30, 572-575. [CrossRef] [PubMed]

51. Sharholy, M.; Ahmad, K.; Mahmood, G.; Trivedi, R.C. Municipal solid waste management in Indian cities-A review. J. Waste Manag. 2008, 28, 459-467. [CrossRef] [PubMed]

52. Guerrero, L.A.; Maas, G.; Hogland, W. Solid waste management challenges for cities in developing countries. Waste Manag. 2013, 33, 220-232. [CrossRef] [PubMed]

53. Srivastava, P.K.; Kulshreshtha, K.; Mohanty, C.S.; Pushpangadan, P.; Singh, A. Stakeholder-based SWOT analysis for successful municipal solid waste management in Lucknow, India. J. Waste Manag. 2005, 25, 531-537. [CrossRef]

54. Rezazadeh, S.; Jahani, A.; Makhdoum, M.; Meigooni, H.G. Evaluation of the strategic factors of the management of protected areas using SWOT analysis-Case study: Bashgol Protected Area-Qazvin Province. Open J. Ecol. 2017, 07, 55-68. [CrossRef]

55. Weihrich, H. The TOWS matrix-A tool for situational analysis. Long Range Plann. 1982, 15, 54-66. [CrossRef]

56. Anselin, A.; Meire, P.M.; Anselin, L. Multicriteria techniques in ecological evaluation: An example using the analytical hierarchy process. Biol. Conserv. 1989, 49, 215-229. [CrossRef]

57. Dyson, R.G. Strategic development and SWOT analysis at the University of Warwick. Eur. J. Oper. Res. 2004, 152, 631-640. [CrossRef]

58. Bernroider, E. Factors in SWOT analysis applied to micro, small-to-medium, and large software enterprises. Eur. Manag. J. 2002, 20, 562-573. [CrossRef]

59. Lozano, M.; Vallés, J. An Analysis of the implementation of an environmental management system in a local public administration. J. Environ. Manag. 2007, 82, 495-511. [CrossRef] [PubMed]

60. Panagiotou, G.; van Wijnen, R. The “Telescopic Observations" framework: An attainable strategic tool. Mark. Intell. Plan. 2005, 23, 155-171. [CrossRef]

61. Brugha, R. Stakeholder analysis: A review. Health Policy Plan. 2000, 15, 239-246. [CrossRef] [PubMed]

62. Zurbrügg, C.; Caniato, M.; Vaccari, M. How assessment methods can support solid waste management in developing countries-A critical review. Sustainability 2014, 6, 545-570. [CrossRef]

63. Bryson, J.M. What to do when stakeholders matter. Public Manag. Rev. 2004, 6, 21-53. [CrossRef]

64. Beecher, N.; Connell, B.; Epstein, E.; Filtz, J.; Goldstein, N.; Lono, M. Public Perception of Biosolids Recycling:Developing Public Participation and Earning Trust; IWA Publishing: London, UK, 2004. 
65. Lindsay, B.E.; Zhou, H.; Halstead, J.M. Factors influencing resident attitudes regarding the land application of biosolids. Am. J. Altern. Agric. 2000, 15, 88-95. [CrossRef]

66. Krogmann, U.; Gibson, V.; Chess, C. Land application of sewage sludge: Perceptions of New Jersey vegetable farmers. Waste Manag. Res. 2001, 19, 115-125. [CrossRef]

67. Caniato, M.; Vaccari, M.; Visvanathan, C.; Zurbrügg, C. Using social network and stakeholder analysis to help evaluate infectious waste management: A step towards a holistic assessment. Waste Manag. 2014, 34, 938-951. [CrossRef]

68. Bryson, J.M.; Patton, M.Q.; Bowman, R.A. Working with evaluation stakeholders: A rationale, step-wise approach and toolkit. Eval. Program. Plann. 2011, 34,1-12. [CrossRef] [PubMed]

69. Eden, C.; Ackermann, F. Making Strategy: The Journey of Strategic Management; SAGE Publications Ltd.: London, UK, 1998.

70. Prell, C.; Hubacek, K.; Reed, M. Stakeholder analysis and social network analysis in natural resource management. Soc. Nat. Resour. 2009, 22, 501-518. [CrossRef]

71. Reed, M.S.; Graves, A.; Dandy, N.; Posthumus, H.; Hubacek, K.; Morris, J.; Prell, C.; Quinn, C.H.; Stringer, L.C. Who's in and why? A typology of stakeholder analysis methods for natural resource management. J. Environ. Manag. 2009, 90, 1933-1949. [CrossRef]

72. Savage, G.T.; Nix, T.W.; Whitehead, C.J.; Blair, J.D. Strategies for assessing and managing organizational stakeholders. Acad. Manag. Perspect. 1991, 5, 61-75. [CrossRef]

73. Mendelow, A.L. Environmental scanning: The impact of the stakeholder concept. In Proceedings of the 2nd International Conference on Information Systems (ICIS), Cambridge, MA, USA, 1981; pp. 407-417. Available online: https://aisel.aisnet.org/ icis1981/20/ (accessed on 30 September 2021).

74. Le, N.; Nguyen, T.; Zhu, D. Understanding the stakeholders' involvement in utilizing municipal solid waste in agriculture through composting: A case study of Hanoi, Vietnam. Sustainability 2018, 10, 2314. [CrossRef]

75. Caniato, M.; Tudor, T.; Vaccari, M. Understanding the perceptions, roles and interactions of stakeholder networks managing health-care waste: A case study of the Gaza Strip. J. Waste Manag. 2015, 35, 255-264. [CrossRef]

76. dos Muchangos, L.S.; Tokai, A.; Hanashima, A. Stakeholder analysis and social network analysis to evaluate the stakeholders of a MSWM system-A pilot study of Maputo City. Environ. Dev. 2017, 24, 124-135. [CrossRef]

77. Methods of Prospective: Mactor. Available online: http://en.laprospective.fr/methods-of-prospective/softwares---cloudversion/22-mactor.html (accessed on 8 August 2021).

78. Bourne, L.; Weaver, P. Mapping stakeholders. In Construction Stakeholder Management; Wiley-Blackwell: Oxford, UK, 2009; pp. 99-120.

79. Johnson, G.; Scholes, K. Exploring Corporate Strategy, 5th ed.; Prentice Hall Europe: London, UK, 1999.

80. Venegas, C.; Sánchez-Alfonso, A.C.; Celis Zambrano, C.; González Mendez, M.; Vesga, F.-J. E. coli CB390 as an indicator of total coliphages for microbiological assessment of lime and drying bed treated sludge. Water 2021, 13, 1833. [CrossRef]

81. MinVivienda. Resolución $N^{\circ} 0330$ Por la cual se Adopta El Reglamento Técnico para el Sector Agua Potable y Saneamiento Básico-RAS; Ministerio de Vivienda, Ciudad y Territorio: Bogotá, Colombia, 2017; pp. 1-182.

82. MinVivienda. Resolución $N^{\circ} 0844$ Se Establecen Los Requisitos Técnicos para los Proyectos de Agua y Saneamiento Básico de Zonas Rurales que se Adelanten Bajo los Esquemas Diferenciales; Ministerio de Vivienda, Ciudad y Territorio: Bogotá, Colombia, 2018; pp. 1-44.

83. MinVivienda; CRA. Resolución CRA 865 DE 2018 Se Definen los Criterios, Metodologías, Indicadores, Parámetros y Modelos de Carácter Obligatorio para Evaluar la Gestión y Resultados de las Personas Prestadoras de los Servicios Públicos Domiciliarios de Acueducto y/o Alcantarillado; Ministerio de Vivienda, Ciudad y Territorio, Comisión de Regulación de Agua Potable y Saneamiento Básico: Bogotá, Colombia, 2018; pp. 1-105.

84. SSPD. Estudio Sectorial de los Servicios Públicos Domiciliarios de Acueducto y Alcantarillado—2018; Superintendencia de Servicios Públicos Domiciliarios: Bogotá, Colombia, 2019; pp. 1-116.

85. CAR. Permiso de Vertimiento y Ocupación del Cauce, Resolución CAR 783; Corporación Autónoma Regional de Cundinamarca: Bogotá, Colombia, 2015; pp. 1-55.

86. PTAR. Planta de Tratamiento de Aguas Residuales domésticas, sitio de estudio. In Informe Semestral de Operaciones PTAR 2019-2020; PTAR: Bogotá, Columbia, 2021; pp. 1-80.

87. CAR. Dirección Operativa y de Infraestructura Ficha Seguimiento Planta de Tratamiento de Aguas Residuales (PTAR) Jurisdicción CAR, Respuesta al Radicado No 20211022572: Información PTAR; Corporación Autónoma Regional de Cundinamarca: Cundinamarca, Colombia, 2019; pp. 1-125.

88. Ginige, K.; Amaratunga, D.; Haigh, R. Mapping stakeholders associated with societal challenges: A methodological framework. Procedia Eng. 2018, 212, 1195-1202. [CrossRef]

89. 40 CFR Part 503-Standards for the Use or Disposal of Sewage Sludge. Available online: https://www.law.cornell.edu/cfr/text/ 40/part-503 (accessed on 14 November 2020).

90. Salazar Espitia, J. Guía Metodológica para El Manejo y Aprovechamiento de Biosólidos en Colombia. Master's Thesis, Universidad Nacional de Colombia, Bogotá, Colombia, 2019.

91. Vivienda. Reglamento para El Reaprovechamiento de los Lodos Generados en las Plantas de Tratamiento de Aguas Residuales. Decreto Supremo No 015-2017; Ministerio del Ambiente: Magdalena del Mar, Perú, 2017; pp. 1-9.

92. Vivienda. Protocolo de Monitoreo de Biosólidos—Resolución Ministerial No 093-2018; Ministro de Vivienda, Construcción y Saneamiento: Lima, Perú, 2018; pp. 1-72. 
93. MAyDS. Norma Técnica Para El Manejo Sustentable de Barros y Biosólidos Generados En Plantas Depuradoras de Efluentes Líquidos Cloacales y Mixtos Cloacales-Industriales en Argentina, Resolución 410/2018; Ministerio de Ambiente y Desarrollo Sostenible: Buenos Aires, Argentina, 2018; pp. 1-15.

94. Conama. Define Critérios e Procedimentos, para o uso Agrícola de Lodos de Esgoto Gerados Em Estações de Tratamento de Esgoto Sanitário e Seus Produtos Derivados, e Dá Outras Providências, Resolução No 375; Conselho Nacional Do Meio Ambiente: Brasilia, Brasil, 2006; pp. 1-32.

95. Conama. Define Critérios e Procedimentos para Produção e Aplicação de Biossólido em solos, e dá outras Providências, Resolução No 498/2020; Ministério Do Meio Ambiente: Brasilia, Brasil, 2020; pp. 1-21.

96. Gianico, A.; Braguglia, C.M.; Gallipoli, A.; Montecchio, D.; Mininni, G. Land application of biosolids in europe: Possibilities, con-straints and future perspectives. Water 2021, 13, 103. [CrossRef]

97. Paes, L.A.B.; Bezerra, B.S.; Deus, R.M.; Jugend, D.; Battistelle, R.A.G. Organic solid waste management in a circular economy perspective-A systematic review and SWOT analysis. J. Clean. Prod. 2019, 239, 118086. [CrossRef]

98. Borgheipour, H.; Moghaddas, Z.; Abbasi, M.; Abbaszadeh Tehrani, N. Application of DEA technique in SWOT analysis of oily sludge management using fuzzy data. Glob. J. Environ. Sci. Manag. 2018, 4, 183-194. [CrossRef]

99. Frise, F.; Ringström, A. SWOT-Analysis of the Introduction and Usage of Faecal Sludge as Fertiliser in Agriculture in the Western Cape Province, South Africa. Bachelor's Thesis, KTH, School of Architecture and the Built Environment (ABE), Sustainable Development, Environmental Science and Engineering, Industrial Ecology, Stockholm, Sweden, 2017.

100. Kantza, E. Evaluation of Methods for Sewage Sludge Utilization: The Greek Perspective. Master's Thesis, Thesis in Energy Systems, School of Science \& Technology, International Hellenic University, Thessaloniki, Greece, 2011.

101. Drechsel, P.; Hanjra, M.A. Wastewater and biosolids for fruit trees (Tunisia)—Case study. In Resource Recovery from Waste: Business Models for Energy, Nutrient and Water Reuse in Low- and Middle-Income Countries; Otoo, M., Drechsel, P., Eds.; Routledge-Earthscan: Oxon, UK, 2018; pp. 569-583.

102. Răducanu, D.; Goldan, E.; Rati, I.V.; Steve Henri Voundi Olugu, I.L. The use of sewage sludge in agriculture: A swot analysis. Studii şi Cercetări. Biologie. Universitatea"Vasile Alecsandri" din Bacău 2015, 24, 18-26.

103. Wójcik, M.; Stachowicz, F.; Masłon, A. Ecological and economic aspects of the application of sewage sludge in energetic plant plantations-A swot analysis. Civ. Environ. Eng. Rep. 2017, 27, 157-168. [CrossRef]

104. Nikolaou, I.E.; Evangelinos, K.I. A SWOT analysis of environmental management practices in Greek mining and mineral industry. Resour. Policy 2010, 35, 226-234. [CrossRef]

105. Goven, J.; Langer, E.R.; Baker, V.; Ataria, J.; Leckie, A. Community engagement in the management of biosolids: Lessons from four New Zealand studies. J. Environ. Manag. 2012, 103, 154-164. [CrossRef] [PubMed]

106. Brown, T.S.; Norberg, L. Building Executive Alignment, Buy-In, and Focus with the Balanced Scorecard SWOT; Harvard Business School Publishing: Boston, MA, USA, 2001; pp. 1-5.

107. Baudino, C.; Giuggioli, N.R.; Briano, R.; Massaglia, S.; Peano, C. Integrated methodologies (SWOT, TOWS, LCA) for improving production chains and environmental sustainability of kiwifruit and baby kiwi in Italy. Sustainability 2017, 9, 1621. [CrossRef]

108. Korableva, O.N.; Kalimullina, O.V. Strategic approach to the optimization of organization based on BSC-SWOT matrix. In Proceedings of the 3rd International Conference on Knowledge Engineering and Applications (ICKEA 2016), Singapore, 28-30 September 2016; pp. 212-215.

109. Cossio, C.; Norrman, J.; McConville, J.; Mercado, A.; Rauch, S. Indicators for sustainability assessment of small-scale wastewater treatment plants in low and lower-middle income countries. Environ. Sustain. Indic. 2020, 6, 100028. [CrossRef]

110. Yudiatmaja, W.E.; Samnuzulsari, T.; Suyito, Y. Transforming institutional design in addressing sludge oil in bintan seawater, Kepulauan Riau, Indonesia. In Proceedings of the The 4th International Conference on Climate Change 2019 (The 4th ICCC 2019), Yogyakarta, Indonesia, 18-19 November 2019; Volume 423, p. 012059. [CrossRef]

111. Robinson, K.G.; Robinson, C.H.; Raup, L.A.; Markum, T.R. Public attitudes and risk perception toward land application of biosolids within the South-Eastern United States. J. Environ. Manag. 2012, 98, 29-36. [CrossRef] [PubMed]

112. Novanda, R.R.; Yunita, E.; Amiruddin, A. factors that influence the intention of consuming vegetables from fertilizing biosolids (human faeces fertilizer). In Proceedings of the International Conference on Environmental Ecology of Food Security, South Sulawesi, Indonesia, 30 March 2020; Volume 681, p. 012040. [CrossRef]

113. El-Hiary, M.; Dhehibi, B.; Awaideh, A.; Omamah Taysir Taher, H.; Mira, H.S.S. Farmers' attitudes towards treated sludge (biosolids) use in agriculture: Evidence from Jordanian badia. Natl. Agric. Res. Cent. 2021, 1-50. Available online: https: / / repo.mel.cgiar.org/handle/20.500.11766/12537 (accessed on 30 September 2021).

114. Ackermann, F.; Eden, C. Strategic management of stakeholders: Theory and practice. Long Range Plann. 2011, 44, 179-196. [CrossRef]

115. Ponce Talancón, H. La matriz FODA: Alternativa de diagnóstico y determinación de estrategias de intervención en diversas organizaciones. CNEIP 2007, 12, 113-130.

116. Cely, B.; Alexandra, V. Metodología de los escenarios para estudios prospectivos. Ing. Inv. 1999, 26-35. [CrossRef]

117. Godet, M.; Durance, P. Strategic Foresight La Prospective Problems and Methods; Godet, M., Pesqueux, Y., Eds.; Cuadernos de LIPSOR: Paris, France, 2006; Volume 20, pp. 1-143.

118. Funciones del Departamento Nacional de Planeación (DNP). Available online: https://www.dnp.gov.co/DNPN/la-entidad/ funciones-dnp (accessed on 23 April 2021). 
119. Objetivos y Funciones MinAmbiente. Available online: https://www.minambiente.gov.co/index.php/ministerio/objetivos-yfunciones (accessed on 10 May 2021).

120. Funciones MinVivienda. Available online: https:/ / minvivienda.gov.co/ministerio (accessed on 10 July 2021).

121. Objetivos y Funciones de la Corporación Autónoma Regional de Cundinamarca (CAR). Available online: https:/ /www.car.gov. co/vercontenido/5 (accessed on 23 April 2021).

122. Funciones del Instituto Colombiano Agropecuario (ICA). Available online: https://www.ica.gov.co/el-ica/funciones (accessed on 23 April 2021).

123. PTAR. Funciones y Deberes de PTAR de La Zona de Estudio (Boyacá, Colombia). Unpublished work. 2021.

124. DEyA. Área de Desarrollo Económico y Agropecuario (Boyacá, Colombia). Unpublished work. 2021.

125. ¿Quiénes Somos?-Empresa Departamental de Servicio Boyacá (ESPB). Available online: https://espb.gov.co/ (accessed on 23 April 2021).

126. Funciones de La Superintendencia de Servicios Públicos Domiciliarios (SSPD). Available online: https://www.superservicios. gov.co/nuestra-entidad/quienes-somos/funciones (accessed on 23 April 2021). 